\title{
Definition and Classification of the Histamine-Release Response to Drugs in Anaesthesia and Surgery: Studies in the Conscious Human Subject ***
}

\author{
W. Lorenz ${ }^{1}$, A. Doenicke ${ }^{2}$, B. Schöning ${ }^{3}$, Ch. Ohmann ${ }^{1}$, B. Grote ${ }^{2}$, and E. Neugebauer ${ }^{1}$ \\ ${ }^{1}$ Division of Theoretical Surgery, Department of Operative Medicine I, University of Marburg, Robert-Koch-Str. 8, D-3550 Marburg, \\ Federal Republic of Germany \\ 2 Division of Anaesthesia, Surgical OPC Clinic, University of Munich, D-8000 Munich, Federal Republic of Germany \\ 3 Division of Anaesthesia, Orthopedic Clinic, University of Heidelberg, D 6900 Heidelberg, Federal Republic of Germany
}

Summary. In 2 clinical studies in 40 conscious human volunteers and 164 orthopedic patients histamine-release responses were diagnosed, defined and classified. Polygeline (Haemaccel) in its now outdated formulation [40] was chosen as a clinical histamine releaser. The main interest was not concentrated on the extreme, the "classical" anaphylactic response, but on the average histamine-release response found in clinical experiments with so many drugs in the last 10 years.

In human volunteers $600 \mathrm{ng} / \mathrm{kg}$ histamine was i.v. injected. Indicants for a systemic anaphylactoid reaction with the highest incidence ratio were tachycardia, plasma histamine levels $>1 \mathrm{ng} / \mathrm{ml}$, "metallic taste", flush, congestion of head, "wet eyes" and tears, hypertension and headache. Following polygeline none of these subjects developed a life-threatening reaction, but 12 showed a systemic response, 11 a cutaneous reaction and 17 were non-responders. Indicants for a systemic anaphylactoid reaction with the highest incidence ratio were plasma histamine levels $>1 \mathrm{ng} / \mathrm{ml}$, tachycardia, wheals, sensation of heat, narrowness of throat, hypertension, headache and wet eyes or tears.

In a prolective, cohort study in the orthopedic patients 3 subjects with life-threatening reactions, 27 with systemic response, 96 with cutaneous reaction and 38 non-responders were included. Indicants with the highest incidence ratio were tachycardia, plasma histamine levels $>1 \mathrm{ng} / \mathrm{ml}$, erythema and wheals, cough, flush, stuffy nose and facial oedema. With this trial the indicants for diagnosing a systemic histamine release response in volunteers were validated in patients to a large extent.

Thus the average histamine-release response was defined by clinical signs such as tachycardia and mild hypertension, scattered hives such as spots of erythema and wheals, respiratory symptoms in the laryngeal and nasal region, such as cough, narrowness in the throat, stuffy nose and sneezing and by pathological plasma histamine levels $(>1 \mathrm{ng} / \mathrm{ml})$. In addition histamine-release responses were differentiated as cutaneous responses, systemic responses and life-threatening responses by clinical and operational criteria and by plasma histamine levels. Using clinical trials and medical

\footnotetext{
* Dedicated to Professor Otto Lindenschmidt

* Supported by grant of Deutsche Forschungsgemeinschaft (Lo 199/10 and Lo 199/13-6)

Offprint requests to: Professor Dr. W. Lorenz (address see above)
}

decision making procedures the incidence of systemic histamine-release responses in patients higher by two orders of magnitude than in other studies reported hitherto.

Key words: Histamine release - Diagnosis - Volunteers Patients - Medical decision making.

\section{Definition und Klassifikation von Histaminfreisetzung nach Gabe von Arzneimitteln in Anästhesie und Chirurgie: Studien am wachen Menschen}

Zusammenfassung: In 2 klinischen Studien bei: 40 wachen Freiwilligen und 164 orthopädischen Patienten wurde versucht, Histaminfreisetzungsreaktionen zu diagnostizieren, zu definieren und zu klassifizieren. Haemaccel in einer heute klinisch nicht mehr verwendeten Zubereitung [40] wurde als klinischer Histaminfreisetzer verwendet. Das Hauptinteresse galt nicht der extremen, der klassischen anaphylaktischen Reaktion, sondern einer durchschnittlichen Histaminfreisetzung, die in klinischen Untersuchungen der letzten 10 Jahre mit so vielen Arzneimitteln gefunden wurde.

Bei den Freiwilligen wurden $600 \mathrm{ng} / \mathrm{kg}$ Histamin intravenös verabreicht. Indikatoren für eine systemische anaphylaktoide Reaktion mit der höchsten Inzidenzrate waren Tachykardie, Plasmahistaminspiegel über $1 \mathrm{ng} / \mathrm{ml}$, metallischer Geschmack, Flush, Kopfdruck, feuchte Augen oder Tränen, Hypertension und Kopfschmerzen. Nach Haemaccel-Infusion zeigte keiner der Probanden eine lebensbedrohliche Reaktion, aber 12 eine systemische und 11 eine Hautreaktion, während bei 17 keine Symptome gefunden werden konnten. Indikatoren mit der höchsten Inzidenzrate waren wiederum Plasmahistaminspiegel über $1 \mathrm{ng} / \mathrm{ml}$, Tachykardie, Quaddeln, Hitzegefühl, Enge im Hals, Hypertension, Kopfschmerzen und Tränen.

In einer prolektiven Cohortstudie wurden aus 600 orthopädischen Patienten 164 ausgewählt: 3 hatten eine lebensbedrohliche Reaktion, 27 eine systemische und 96 eine Hautreaktion, 38 Patienten zeigten keine Symptome. Indikatoren mit der höchsten Inzidenzrate waren wiederum Tachykardie, Plasmahistaminspiegel über $1 \mathrm{ng} / \mathrm{ml}$, Erytheme und Quaddeln, Husten, Flush, verstopfte Nase und Gesichtsödem. Damit wurden durch die Patientenstudie die Indikatoren für eine systemische Histaminfreisetzungsreaktion in Probanden zu einem großen Teil validiert. So läßt sich eine durchschnittliche Histaminfreisetzungsreaktion als eine systemische anaphylaktoide Reaktion charakterisieren, 
mit klinischen Symptomen wie Tachykardie und leichte Hypertension, verstreuten Effloreszenzen, respiratorischen Symptomen im Bereich des Kehlkopfs und der Nasenschleimhaut und durch pathologische Plasmahistaminspiegel $(>1 \mathrm{ng} / \mathrm{ml})$. Außerdem wurden die Histaminfreisetzungsreaktionen in kutane, systemische und lebensbedrohliche Reaktionen eingeteilt, wobei klinische und operationale Kriterien sowie Plasmahistaminspiegel für die Klassifikation verwendet wurden.

Schlüsselwörter: Histaminfreisetzung - Diagnose - Probanden - Patienten - Medizinische Entscheidungsfindung.

\section{Introduction}

Before reliable and practicable [20] histamine assays in human plasma became available for routine use $[4,26,27]$ a histamine-release response to drugs could not be estimated in clinical conditions with an acceptable accuracy $[9,10,28,29,34,36,45,51,58,62]$. But even one decade after the discovery of $\mathrm{H}_{2}$-receptor antagonists [5] and the development of these highly sensitive and specific asays [4, 26] histamine was still not generally recognized as an important mediator of any pathological and clinical phenomenon [63]. It was something of a paradigm [22a] not to assign any distinct function to this biogenic amine - neither qualitatively nor quantitatively [13].

In the labyrinth of intricate views on histamine this disappointing situation could be amended by only step by step. A very early, necessary and urgent one was to establish the diagnosis of the histamine-release response to an individual drug in clinical conditions, especially in anaesthesia and surgery where so many histamine-releasing drugs are routinely administered intravenously [39]. The main interest in this study therefore was not concentrated on the extreme, the "classical anaphylactic" response, but on the average response which was found in clinical experiments with so many drugs during the last 10 years. Thus two aims were devised in this investigation:

(1) In conscious human volunteers clinical symptoms and plasma histamine levels were assessed after intravenous injection of histamine. A dose was chosen which increased the plasma histamine levels to such an extent as the average histamine-release response to drugs used in anaesthesia [28, 34]. In addition, the same subjects received one of the "clinical" histamine releasers, polygeline (Haemaccel) [29, 34, $39,40)$ a short time after exogenous histamine. From all the findings a questionnaire with many items was developed to diagnose an average histamine-release response.

(2) Using these items in conscious orthopedic patients the clinical symptoms, biological reactions and plasma histamine levels were assessed which were elicited by Haemaccel, the same histamine liberator as used in the volunteers. By this study the set of indicants for diagnosing a histaminerelease response was validated. Parts of this very extended study have already been published in other journals [1, 35-40]. The subject of this presentation, however, was not considered in the previous communications.

\section{Materials and Methods}

\section{Theoretical and Ethical Issues [41]}

The aim of the study could not be achieved by a single technique (e.g. a single biochemical test). Among several approaches a de-

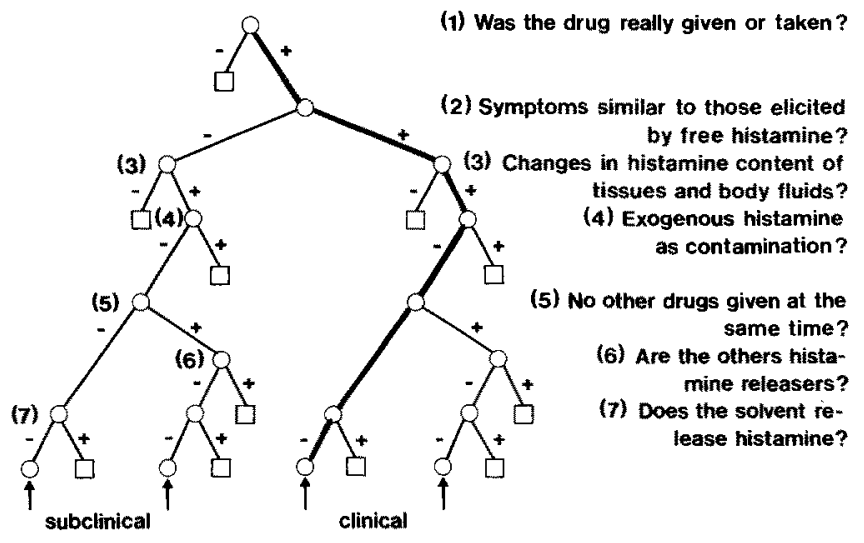

\section{OK! The patient has a histamine-release response to the drug}

Fig. 1. Decision tree for diagnosis of histamine-release response to an individual drug in an individual patient. The open circles represent test nodes, the plus or minus branches the preceding facts or findings which are necessary to establish finally the diagnosis. The tree structure was performed according to Lusted [43]. The small squares denote steps of the decision-making process (dead ends), not choice nodes as in a modified system of displaying the decision problem [68]. The arrows indicate the final outcome of a clinical or subclinical histamine-release response

cision-making process was chosen for a first approximation which was illustrated by a decision tree (Fig. 1). The designs of the two prospective studies in volunteers and patients payed regard to all the questions in this structure.

The decision tree showed 4 paths and 3 outcomes comprising clinical, subclinical and indeterminable histamine-release response to an individual drug. Subclinical reactions were included since they were of considerable interest for a second drug exposure and other complications after surgery [66]. For the aims of the two clinical trials, however, the second path from the right was the most important one including symptoms, changes in plasma histamine content, no contamination with exogenous histamine, no other histamine releasers given and a highly inert solvent system. Since the final outcome (diagnosis of a clinical response) should depend mainly on findings obtained by the questions 2 and 3 , the studies had to be conceived in such a way that the other information was obtained with the highest possible precision and accuracy.

To achieve this aim the following conditions numbered in agreement with the decision tree were chosen:

(1) Exogenous histamine and the histamine releaser polygeline (Haemaccel) were given to the human subjects by a single investigator (author), to volunteers by B.G. and to patients by B.Sch.

(2) Clinical signs were recorded by a single observer, too, in volunteers by W.L. and in patients by B.Sch. Thus observer variation within the trials could be avoided. Between the trials it was reduced by discussions in detail of all defintions of the various indicants by the observer in volunteers with the observer in patients [16, 43].

In volunteers a dose of $600 \mathrm{mg} / \mathrm{kg}$ i.v. exogenous histamine was expected to produce plasma histamine levels similar to those of an average histamine-release response (pilot study in volunteers and in dogs [30]). An injection was chosen because of pharmacokinetics more similar to histamine release than histamine infusion. The intravenous route corresponded to histamine release from the skin which is common for many histamine liberators [47] including Haemaccel [30]. To avoid tachyphylaxis and prolonged elevation of plasma histamine content exogenous histamine was applied be* fore polygeline.

Polygeline was tested in a dose of $500 \mathrm{ml} / 3 \mathrm{~min}$ in normovolaemic haemodiluation [34] since this design repeatedly has produced average histamine-release responses $[28,33-35,54]$. Hae- 
maccel as a plasma substitute was pure and chemically defined and could be administered in clinical conditions where no other drug, solvent or treatment interferes [34]. Histamine release by this drug was predominant $[13,35]$ i.e. no other mediator seemed to be of any importance in the reaction to polygeline [35]. Its incidence was sufficiently high in clinical situations and its mechanisms were reasonably uniform $[39,40,56]$.

In patients the infusion of $500 \mathrm{ml} / 10 \mathrm{~min}$ Haemaccel before operation was indicated for therapeutic reasons [62a]. This decision was made by clinicians responsible for the patients and not by those involved in the trial. The administration of polygeline in conscious patients, however, was utilized for this study since anaesthesia was considered to modify, but not in general to reduce the extent of the clinical reaction [46].

(3) All plasma histamine assays were performed by a single technician who was not aware of the clinical reactions and received the plasma samples in a randomized sequence. The assays run under quality control using a mixed control plasma prepared from the patients of the trial in Heidelberg and control charts according to Levey and Jennings [24].

(4) Polygeline was tested in several batches to obtain a random distribution of histamine-release responses over the manufacturing process. In none of the 4 batches administered to volunteers and patients could any histamine contamination be detected. In addition, the fluorescent material in polygeline [31] was shown not to interfere with the histamine assay using several tests of identification [32].

(5) Interference with other drugs was prevented by controlling meticulously the time before and after histamine and polygeline administration. Histamine release was considered as a sudden event with an explosive velocity of increment for plasma histamine levels [36] followed by a rather quick elimination (plasma $t^{1} / 2$ for $i$. v. injected histamine about $2 \mathrm{~min}$, for histamine release about 5-10 $\mathrm{min}[30$, 36].

Thus in volunteers all subjects were systematically asked for any drug intake at the day of experiment by a single observer (W.L.) and 2 of them were excluded since this was the case. Following i.v. histamine injection $20 \mathrm{~min}$ elapsed before polygeline was infused. Basal plasma histamine levels were again attained at this time (Fig. 5).

In patients only elective surgery was accepted. The night before operation they received standard treatment (only nitrazepam and heptabarbitone). In the morning the premedication for anaesthesia started with the infusion of polygeline. Inovar (in Germany known as Thalamonal) and atropine, the other two components of the premedication were administered not prior than 30 min after the start of infusion which lasted not longer than 10 min. Patients who needed additional drugs for treatment of concomitant diseases such as $\beta$-adrenoceptor blocking drugs or digitalis received these compounds very early in the morning and not later than $2 \mathrm{~h}$ before starting the infusion of polygeline.

(6) In clinical conditions none of these drugs was hitherto suspected to be a histamine releaser $[36,39]$.

(7) Histamine was dissolved in saline and polygeline in a slightly modified Ringer solution which was shown not to release histamine [34].

Ethical Justification. In volunteers informed consent was obtained in written form following an extensive discussion about the importance and necessity of the study, the experimental design and the risks of a histamine injection, blood donation and infusion of a histamine releaser. It was explained that at the time of the study (March 1976) no colloidal plasma substitute commercially available was entirely without risk of inducing an anaphylactoid response $[34,52,54]$. At the time of the study polygeline it its now outdated formulation ("classical polygeline" [40]) had been given to patients all over the world for more than 10 years. Utmost safety was provided for each volunteer during the clinical experiment by at least 2 anaesthesists being present in the room all the
Table 1. Attributes of the subjects in the volunteer study

\begin{tabular}{ll}
\hline Attributes & $\begin{array}{l}\tilde{\mathrm{x}} \text { (interquartile } \\
\text { range, range) }\end{array}$ \\
\hline Age [years] & $26(23-29,21-37)$ \\
Weight [kg] & $70(62-75,50-94)$ \\
& Ratio of numbers \\
Sex (male/female) & $32 / 8$ \\
Profession (S-M, S-NM, HS, NHS) & $12 / 13 / 10 / 5$ \\
Allergy in past (yes/no) & $9 / 31$ \\
Allergy at present (yes/no) & $10 / 30$ \\
Previous infusion of colloidal & $10 / 30$ \\
$\quad$ plasma substitutes (yes/no) &
\end{tabular}

S-M student of medicine, S-NM student not studying medicine, HS hospital staff, NHS other professions, but not hospital staff (e.g. civil servant, engineer, photographer). Allergy in past $=$ more than 9 months ago, allergy at present =from 9 months in the past until now. Previous infusion of plasma substitutes included 9 subjects who were included in previous trials (the last 2 years before)

time. All emergency equipment was in the room and ready for use. In addition, all volunteers were asked to inform the investigators the day after the experiment about their state of health. There was no complaint by any of them.

In orthopaedic patients no safer alternative treatment was available. The patients were informed about additional taking of blood samples for plasma histamine assays. Utmost safety was provided for each patient in the same way as for each subject in the volunteer study.

\section{Time Schedule, Volunteers and Patients, Materials}

The volunteer study was conducted in 40 subjects (Table 1) in Munich at March 8-13, 1976. For this trial histamine dihydrochloride puriss. (Fluka, Buchs) was dissolved in sterile saline $(2 \mathrm{mg} / 100 \mathrm{ml}$, University's pharmacy). Only $2.5-5 \mathrm{ml}$ were injected to achieve a reliable bolus injection. - Polygeline (Haemaccel, Behringwerke Marburg) was infused in 4 batches (Op 3000 and 3812, V-235 and V-244) which were characterized in previous communications $[31,32,34,40]$ regarding their chemical and pharmacological properties. The 40 volunteers were assigned to 4 treatment groups (1 batch for one group) by a balanced random allocation with random digits. This part of the study was a double-blind trial [40]. The patient study was conducted in 164 subjects in Heidelberg from March 14, 1977 till January 12, 1978. They were selected from 600 patients in a controlled clinical trial $[36,38-40]$ who after prolective stratification comprised both sexes divided into 5 classes of age ( $20-\geqq 60$ years, 30 patients in each cell). The selection became necessary since the plasma histamine assays were too time-consuming and expensive to be carried out in all patients. The procedure for selection is shown in Table 2: (1) In all participants of the trial with clinical symptoms of an anaphylactoid reaction [35] blood was taken for plasma histamine assays. From a previous trial [54] 30 incidents were expected and fortunately also found. (2) To avoid seasonal variations or bias introduced by new drugs or treatment during the study the control group with "no adverse response" was formed by selecting always the next two patients following the last one with an anaphylactoid reaction. It was expected that some of these patients would develop an allergoid reaction (response restricted to the skin) [35]. By that the sample of true non-responders would be reduced to approximately the same size as that of the sample with anaphylactoid reactions. In this aspect the selection was rather successful (Table 2). (3) Then a second control group was formed with patients "showing only allergoid reactions" to discriminate between anaphylactoid (systemic) and allergoid (cutaneous) reactions to polygeline. For this clinically very important classification a compromise was chosen 
Table 2. Patients in the clinical trial on histamine release by polygeline and proportions of those involved in the plasma histamine assay

\begin{tabular}{|c|c|c|c|c|c|c|}
\hline \multirow{3}{*}{$\begin{array}{l}\text { Reaction } \\
\text { to polygeline }\end{array}$} & \multicolumn{3}{|c|}{ Expected $^{\mathrm{a}}$} & \multicolumn{3}{|c|}{ Found } \\
\hline & \multicolumn{2}{|c|}{$\begin{array}{l}\text { Patients } \\
\text { in trial }\end{array}$} & \multirow{2}{*}{$\begin{array}{l}\text { Pro- } \\
\text { portion } \\
\text { for } \\
\text { hista- } \\
\text { mine }\end{array}$} & \multicolumn{2}{|c|}{$\begin{array}{l}\text { Patients } \\
\text { in trial }\end{array}$} & \multirow{2}{*}{$\begin{array}{l}\text { Pro- } \\
\text { portion } \\
\text { for } \\
\text { hista- } \\
\text { mine }\end{array}$} \\
\hline & {$[\mathrm{n}]$} & {$[\%]^{\mathrm{b}}$} & & {$[\mathrm{n}]$} & {$[\%]$} & \\
\hline Anaphylactoid & 30 & 5 & 30 & 30 & 5 & 30 \\
\hline No response & 420 & 70 & 50 & 413 & 69 & 38 \\
\hline Allergoid & 150 & 25 & 100 & 157 & 26 & 96 \\
\hline Total & 600 & 100 & 180 & 600 & 100 & 164 \\
\hline
\end{tabular}

a Frequencies and rate according to Schöning and Koch [54]

b Percentage of patients in the trial. 4 patients in the third group were lost by failures of centrifugation, 4 were excluded because they could not unequivocally be classified as "no responders" or "patients with allergoid reaction". Sex distribution (male/female) in the three groups: Anaphylactoid 24/6, no response 16/22, allergoid 56/40 patients. Age distribution in the three groups (20-29, $30-39,40-49,50-59, \geqq 60$ years): Anaphylactoid 6/10/5/6/3 - no response $7 / 8 / 7 / 8 / 8$ - allergoid $18 / 20 / 29 / 14 / 15$. The differences were not considered as influencing the incidence ratio of pathological plasma histamine levels and clinical symptoms

between maximum information and feasibility selecting two-thirds of patients with allergoid reactions for plasma histamine assays by random allocation with random digits. Selection and randomization procedure could only be realized because plasma was prepared from all 600 patients in the study before polygeline infusion. Plasma of patients which was not used for histamine assays was pooled for quality control samples.

Polygeline was infused in 4 batches (Op 3939 and 3946, V-244 and V-265). The 600 patients were assigned to 4 treatment groups (1 batch for one group). This part of the study again was a doubleblind trial. However, no differences were found in the incidence of reactions between the 4 batches [38].

Reagents for plasma histamine assays were the same as described by Lorenz et al. [27, 32].

\section{Experimental Design}

(1) In volunteers the investigation started with a half-structural interview including questions on case history to identify special risks of anaphylactoid reactions to plasma substitutes [34], questions on previous exposure to intravenous agents $[28,65,66]$ and on clinical signs appearing even before injection of histamine. The clinical symptoms were chosen from previous reports $[23,59,69]$ and earlier studies $[28,33,34]$. The volunteer was asked to give his informed consent.

Thereafter in the laying subject leads for the ECG were attached to the extremities and a sphygmomanometer was applied to the right upper arm. Two Braunulae were inserted in this arm, one in the cubital fossa for injection of histamine and one more peripheral for the venous blood collection. A first $20 \mathrm{ml}$ sample was taken to produce plasma for a pool which was used for quality control samples. Five minutes later a second sample was taken to obtain the pre-injection plasma histamine level. Then histamine was administered and blood was taken at 1,2, 3,5 and 10 min after its application. During this time the volunteer was asked about and carefully looked for any clinical symptoms. First of all, spontaneous reactions were recorded, then all questions asked before the injection were repeated 3 and $10 \mathrm{~min}$ after histamine injection.
Fifteen minutes after histamine injection blood donation $(360 \mathrm{ml})$ was started from the left arm and $1 \mathrm{~min}$ later polygeline was infused $(500 \mathrm{ml}$, in about $3 \mathrm{~min})$. Blood samples for plasma histamine were taken $1,5,10,15$ and $20 \mathrm{~min}$ after the end of infusion and during this time the clinical symptoms were recorded as described before. Thoughout the experiment the heart rate was continuously monitored (lead II in ECG) and the blood pressure was measured every min.

From the questions, observations and responses of the volunteers a questionnaire was developed with indicants for diagnosing a histamine-release response (Appendix 1).

(2) Also in patients the investigation started with an interview using the questionnaire in a protocol ready for electron data processing [57]. Then pulse rate (by hand) and blood pressure (by sphygmomanometer) were measured and a large arm vein was cannulated by a Braumula No.1. For plasma histamine assay blood samples were taken $5 \mathrm{~min}$ later before polygeline $(500 \mathrm{ml})$ was infused in 10-15 min, at the end of the infusion and again 5 min later to get parts of a clearance curve as in the volunteers [39]. At the end of the infusion, 5, 15 and 30 min later pulse and blood pressure were measured and any clinical symptoms - especially any skin reactions - were systematically looked for even by turning the patient round and inspecting all parts of the body. The protocol was tested for its completeness and any observations to be added were specified. For plasma preparation [27] blood was centrifuged in a Minifuge (Christ, Osterode) in the operation theatre [27].

\section{Methods}

Clinical symptoms and reactions were assessed using the questionnaire described in this communication. - Plasma was prepared and plasma histamine concentration was determined according to Lorenz et al. [27] using a sensitive and specific fluorometric-fluoroenzymatic assay. - In all cases with anaphylactoid reactions histamine was identified by fluorescence spectra, heating test and spectra after the heating test as described by Lorenz et al. [32] and Parkin et al. [48]. - All assays were performed under quality control using two plasma pools obtained from volunteers and patients to which authentic histamine was added to give "plasma" histamine levels similar to those of an average histamine-release response (about $3 \mathrm{ng} / \mathrm{ml}$ ).

\section{Statistics and Definitions}

For descriptive statistics median, interquartile range, range and incidence ratio were used, for inferential statistics $95 \%$ confidence intervals and decision-making matrix $[15,43,68]$. The correlation between plasma histamine levels and increase in heart rate (tachycardia) was analysed by the method of least squares using a Hewlett-Packard computer HP 9815 A.

A crucial question in this study was the definition of the "disease". In the first part of the volunteer study the disease was an anaphylactoid-like reaction to the i.v. injection of histamine, in the second part of this study and in the clinical trial the disease was a true anaphylactoid or allergoid (cutaneous anaphylactoid) reaction to polygeline. The similarity of the two "diseases" in terms of diagnosis was one of the most important questions of this article.

Thus anaphylactoid and allergoid reactions have to be defined [39]: (1) An anaphylactoid reaction is a clinical reaction with generalized urticaria (more than 5 wheals in different regions of the body), discomfort (nasal catarrh, narrowness of the throat, blepharoedema, nausea or vomiting, diarrhoea), bronchospasm, tachycardia, hypotension, circulatory and cardiac insufficiency and arrest. At least generalized urticaria phus discomfort (except dermal pruritus) were necessary to classify an adverse reaction to drugs as anaphylactoid. Generalized urticaria plus tachycardia, but also bronchospasm, cardiac arrhythmia, hypotension or cardiac arrest with or without urticaria are other combinations of clinical signs being classified as anaphylactoid. (2) An allergoid (cutaneous anaphylactoid) reaction is again a clinical reaction classified by erythema, urticaria and dermal pruritus only, Lateron in this article 


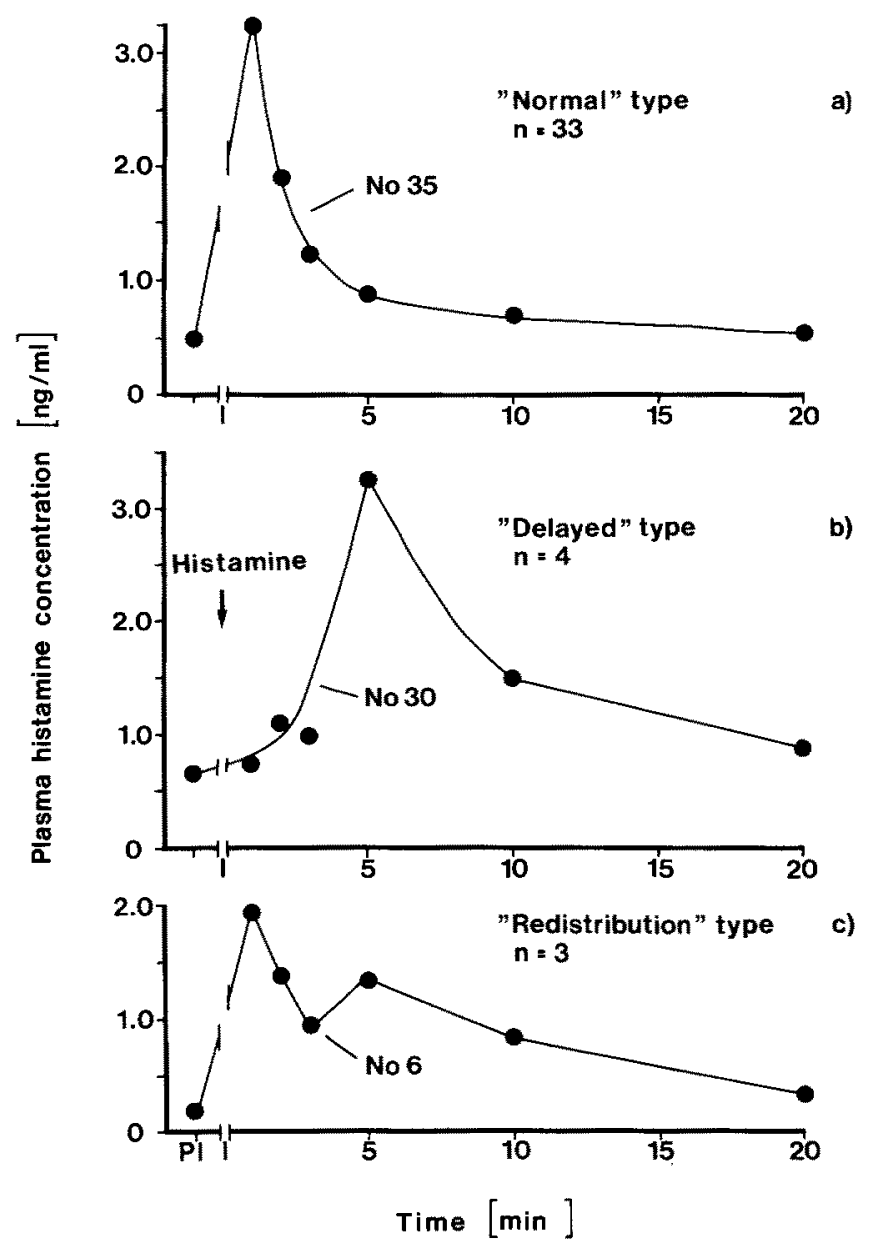

Fig. 2. Histamine elimination curves following i.v. injection of exogenous histamine $(600 \mathrm{ng} / \mathrm{kg})$. Single values obtained from the volunteers. $n$ refers to the number of subjects showing the attribute, No refers to the number of a single person in the sequence of the experiments. Since in one of the subjects only the first sample after histamine injection was lost, but all other values corresponded to those of the type-(a)-elimination curve this subject was not excluded in the figure. For further conditions see Materials and Methods anaphylactoid reaction will be replaced by systemic histamine-release response. In terms of taxonomy of diseases the systemic histamine-release response is a special case of an anaphylactoid reaction which in its turn is a special case of a pseudo-allergic reaction $[12,22,39]$.

Another crucial question in this study was the defintion of a pathological plasma histamine level as indicant for an anaphylactoid reaction. (1) It is defined as top level obtained by measuring several values in a Bateman function. (2) It is defined as positive or pathological if it is higher than $1 \mathrm{ng} / \mathrm{ml}$ which is the upper 2 SD limit of the "normal range". Considering well the criticism of this concept [18] it is emphasized that since 1975 the normal range of plasma histamine values has been always $0-1 \mathrm{ng} / \mathrm{ml}$ in studies with 120 [33] and 40 [37] volunteers and in 50 [39] and 299 [55] patients of both sexes and 5 classes of age using our fluorometric-fluoroenzymatic assay $[27,39]$.

\section{Results}

\section{Plasma Histamine Levels and Clinical Signs in Volunteers Following Administration of Exogenous Histamine}

Histamine elimination curves showed 3 typical patterns (Fig. 2): A "normal" type in $80 \%$ of the subjects showed first-order kinetics, but in $20 \%$ a "delayed" type or a "redistribution" type was found, probably due to difficulties with the bolus injection. Such "failures"occur also in clinical routine [39]. For assessing the incidence ratio, however, the pathological plasma histamine values the one subject in whom the first plasma was lost and the three with "redistribution" type curves were excluded (Fig. 3, Table 3).

From the data in the other 36 volunteers, however, it was evident, that the imitation of an anaphylactoid reaction by injection of histamine was reasonably successful (Fig. 3). Eighty percent of the plasma histamine levels exceeded $1 \mathrm{ng} /$ $\mathrm{ml}$ and the average concentration was about $1.5-2 \mathrm{ng} / \mathrm{ml}$, similar to that found in histamine-release responses to anaesthetics and plasma substitutes [10,34]. In 2 subjects plasma histamine levels of about $4 \mathrm{ng} / \mathrm{ml}$ were measured, accompanied by considerable tachycardia. In 8 subjects increases of plasma histamine levels could be determined, but were rather small and did not exceed the normal range. The variation in plasma histamine levels following the same

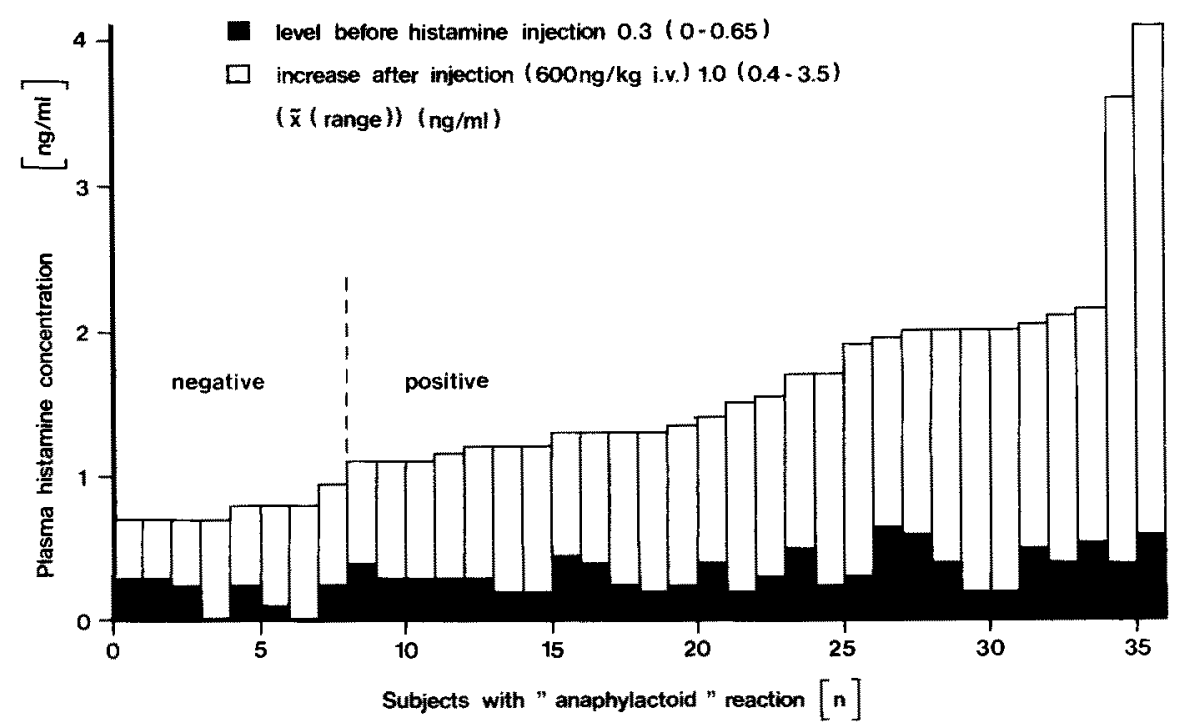

Fig. 3. Plasma histamine levels before and after injection of histamine in volunteers in whom an anaphylactoid reaction was imitated by i.v. administration of only $600 \mathrm{ng} / \mathrm{kg}$ histamine. Single values obtained from each of the volunteers before and after histamine injection. The vertical dotted line indicates the cut-off point for an anaphylactoid reaction as described in Methods 
Table 3. Incidence ratio for pathological plasma histamine levels and clinical signs in "anaphylactoid" reactions imitated in volunteers by i.v. injection of histamine

\begin{tabular}{|c|c|c|c|c|}
\hline \multicolumn{2}{|l|}{ Symptom } & \multicolumn{3}{|c|}{ Incidence } \\
\hline & & \multirow{2}{*}{$\begin{array}{l}\mathrm{n}_{1} / \mathrm{n}_{2} \\
28 / 36\end{array}$} & \multirow{2}{*}{$\begin{array}{r}\% \\
78 \\
\end{array}$} & \multirow{2}{*}{$\begin{array}{l}95 \% \\
\text { confi- } \\
\text { dence } \\
\text { interval }\end{array}$} \\
\hline Plasma hista & mine level $>1 \mathrm{ng} / \mathrm{ml}$ & & & \\
\hline Skin: & $\begin{array}{l}\text { Flush } \\
\text { Erythema } \\
\text { Sensation of heat } \\
\text { Wheals }\end{array}$ & $\begin{array}{r}25 / 36 \\
4 / 36 \\
20 / 36 \\
0 / 36\end{array}$ & $\begin{array}{r}69 \\
11 \\
56 \\
0\end{array}$ & $\begin{array}{r}51-84 \\
3-27 \\
38-73 \\
0-10\end{array}$ \\
\hline $\begin{array}{l}\text { Respiratory } \\
\text { tract: }\end{array}$ & $\begin{array}{l}\text { Narrowness of chest } \\
\text { Coughing } \\
\text { Stoffy nose }\end{array}$ & $\begin{array}{r}11 / 36 \\
0 / 36 \\
0 / 36\end{array}$ & $\begin{array}{r}31 \\
0 \\
0\end{array}$ & $\begin{array}{r}16-49 \\
0-10 \\
0-10\end{array}$ \\
\hline Circulation: & $\begin{array}{l}\text { Tachycardia } \\
\text { Hypotension } \\
\text { Hypertension } \\
\text { Pulsation at temples }\end{array}$ & $\begin{array}{r}35 / 36 \\
6 / 36 \\
21 / 36 \\
14 / 36\end{array}$ & $\begin{array}{l}97 \\
17 \\
58 \\
39\end{array}$ & $\begin{array}{c}85-100 \\
6-33 \\
40-75 \\
23-57\end{array}$ \\
\hline Abdomen: & $\begin{array}{l}\text { Nausea } \\
\text { Metallic taste } \\
\text { Salivation }\end{array}$ & $\begin{array}{r}2 / 36 \\
27 / 36 \\
4 / 36\end{array}$ & $\begin{array}{r}3 \\
75 \\
11\end{array}$ & $\begin{array}{r}0-19 \\
57-88 \\
3-27\end{array}$ \\
\hline $\begin{array}{l}\text { CNS and } \\
\text { ANS: }\end{array}$ & $\begin{array}{l}\text { Headache } \\
\text { Outbreak of sweat } \\
\text { "Wet eyes" } \\
\text { Congestion of head }\end{array}$ & $\begin{array}{r}21 / 36 \\
5 / 36 \\
23 / 36 \\
24 / 36\end{array}$ & $\begin{array}{l}58 \\
14 \\
64 \\
67\end{array}$ & $\begin{array}{r}40-75 \\
4-30 \\
46-80 \\
49-82\end{array}$ \\
\hline
\end{tabular}

Each symptom was recorded only once in a single volunteer. $\mathrm{n}_{1}=$ number of subjects showing the symptom provided histamine was given, $\mathrm{n}_{2}=$ number of subjects having the "anaphylactoid" reaction. All volunteers responded and fulfilled the conditions of the definition (see Materials and Methods). No treatment, however, was necessary in any of them (cf. Tables 4 and 5) dose of histamine was about 10 -fold - a finding with some clinical relevance. The increases in plasma histamine concentration following histamine injection were not normally distributed (cf. [30]) and were not correlated to the basal plasma histamine levels. All these findings indicated a more complex situation for histamine elimination than the rather simple clearance curves (Fig. 3) had suggested. At least excretion by the kindey and gastro-intestinal tract, up-take into several tissues and a rapid metabolism were identified hitherto as components in elimination [39].

The incidence ratio of pathological plasma histamine levels and clinical signs of an "anaphylactoid" reaction varied considerably from indicant to indicant (Table 3). Although histamine was actually given to all volunteers and all of them showed clinical signs of a systemic response plasma histamine levels exceeding $1 \mathrm{ng} / \mathrm{ml}$ were found only in $80 \%$ of them. The clinical sign with the highest incidence was tachycardia, followed by sensation of an unusual ("metallic") taste, flush, congestion of head, "wet eyes", headache and hypertension(!). Classical symptoms of anaphylactoid reactions such as wheals, respiratory symtoms and hypotension could not be observed. Although this is quite understandable (wheals occur only at high local histamine concentrations, respiratory and hypotensive responses appear at usually higher histamine concentrations), this finding is of general clinical importance. An average histamine-release response may not be diagnosed in clinical conditions because the place of histamine release may not be the skin, but the gut (cremophor El [39]) and because local histamine release in a vital organ such as the heart may not lead to cutaneous and respiratory symptoms, but only to misinterpreted "unspecific" heart symptoms [25, 26a]

A logical consequence of these conclusions was the question of which symptoms appeared at which plasma histamine concentrations. In the volunteer study there was no clear trend to establish such a relationship (Fig. 4). Howev-

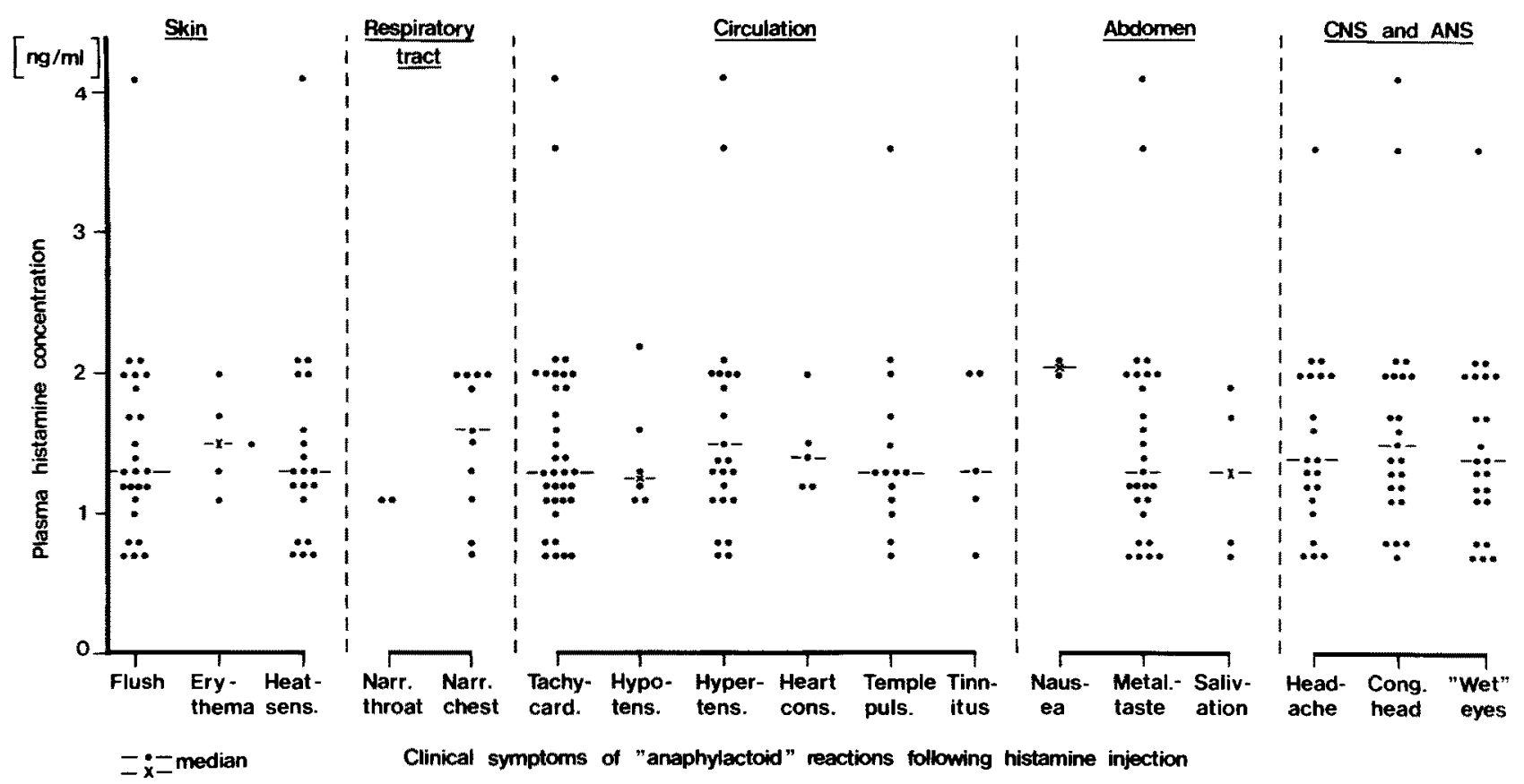

Fig. 4. Plasma histamine levels and clinical signs of an "anaphylactoid" reaction in volunteers imitated by the i.v. injection of histamine. Each symptom and plasma histamine level was recorded only once in a single volunteer. $n=36$. $C N S=$ central nervous system, $A N S=$ autonomous nervous system. For abbreviations of the other symptoms use Tables 3-5 and Appendix 1 of this communication 

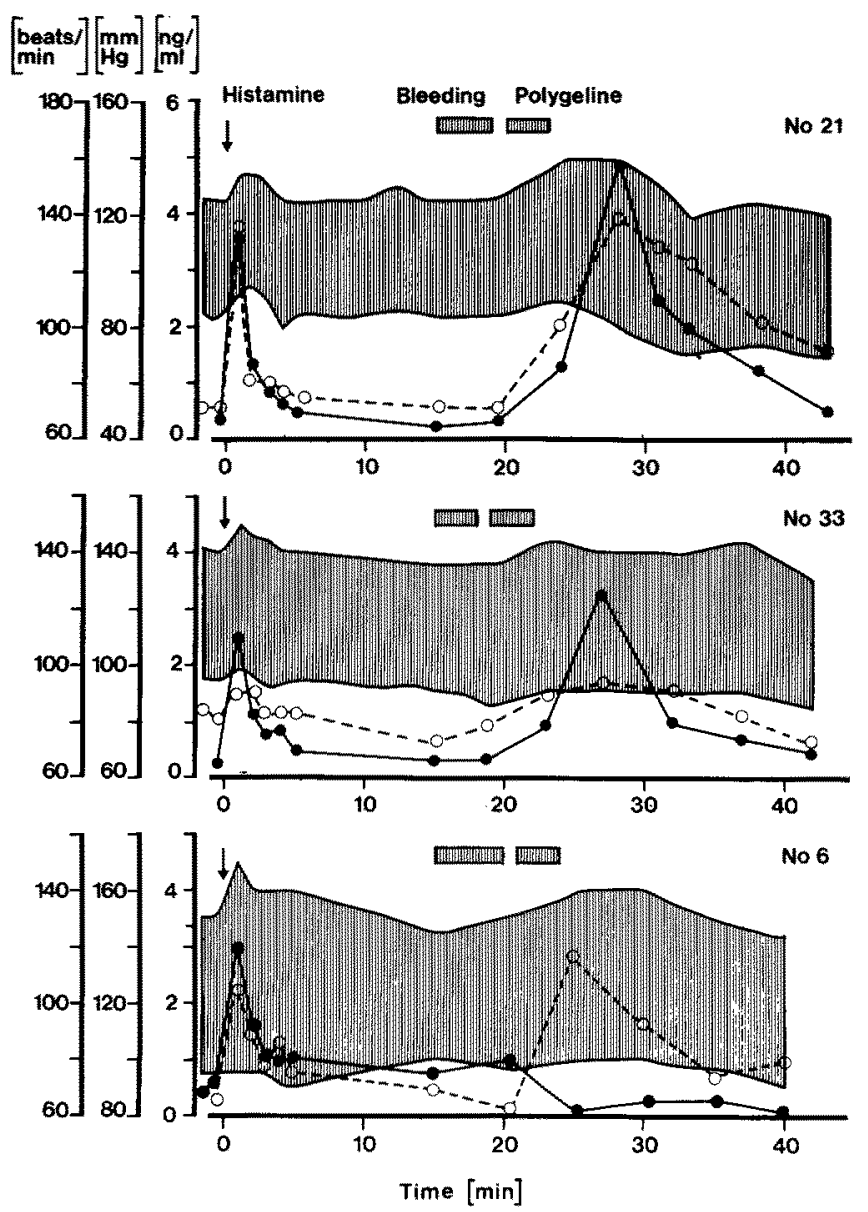

Fig. 5. Plasma histamine levels and circulatory parameters in three volunteers with an anaphylactoid reaction to polygeline. Values following histamine injection and subsequent infusion of "classical" Haemaccel. Single values obtained from each volunteer. - heart rate, o--o, plasma histamine concentration,

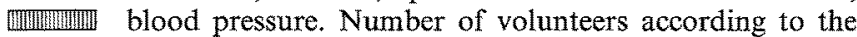
sequence in trial. Histamine $=600 \mathrm{ng} / \mathrm{kg}$ of histamine base i.v. as a bolus injection

er, several symptoms were rare and occurred at higher plasma histamine levels, such as sensations of "narrowness in the chest" and nausea.

\section{Plasma Histamine Levels and Clinical Signs in Volunteers Following Infusion of Polygeline}

Of 40 volunteers receiving all the full dose of polygeline 12 responded with an anaphylacoid reaction. They showed plasma histamine values of $0.3(0-1.0) \mathrm{ng} / \mathrm{ml}(\tilde{\mathrm{x}}$ and range) before and $1.9(0.7-4.2) \mathrm{ng} / \mathrm{ml}$ after polygeline infusion. One subject fulfilled the criteria of an anaphylactoid reaction, but his plasma histamine levels increased only from 0 to $0.7 \mathrm{ng} / \mathrm{ml}$ and remained within the normal range. Since otherwise the data on plasma histamine were very similar to those obtained whith histamine injection a more extended presentation in this chapter is omitted.

To illustrate, however, the relations between plasma histamine levels, heart rate and blood pressure the 3 most impressive reactions in volunteers were shown in Fig. 5. In subject No 6 instead of tachycardia bradycardia was observed which was the only case in the series and hitherto had been found only in very rare cases of histamine release.
Table 4. Incidence ratio for pathological plasma histamine levels and clinical signs in anaphylactoid reactions in volunteers following infusion of polygeline

\begin{tabular}{|c|c|c|c|c|}
\hline \multicolumn{2}{|l|}{ Symptom } & \multicolumn{3}{|c|}{ Incidence } \\
\hline & & $\mathrm{n}_{1} / \mathrm{n}_{2}$ & $\%$ & $\begin{array}{l}95^{\circ} \\
\text { confi- } \\
\text { dence } \\
\text { interval }\end{array}$ \\
\hline \multicolumn{2}{|c|}{ Plasma histamine level $>1 \mathrm{ng} / \mathrm{ml}$} & $11 / 12$ & 92 & $61-100$ \\
\hline Skin: & $\begin{array}{l}\text { Flush } \\
\text { Erythema } \\
\text { Sensation of heat } \\
\text { Wheals }\end{array}$ & $\begin{array}{l}4 / 12 \\
3 / 12 \\
6 / 12 \\
7 / 12\end{array}$ & $\begin{array}{l}33 \\
25 \\
50 \\
58\end{array}$ & $\begin{array}{r}9-66 \\
5-58 \\
21-79 \\
27-85\end{array}$ \\
\hline $\begin{array}{l}\text { Respi- } \\
\text { ratory } \\
\text { tract: }\end{array}$ & $\begin{array}{l}\text { Sneezing } \\
\text { Stoffy nose } \\
\text { Narrowness of the throat } \\
\text { Coughing } \\
\text { Respiratory distress } \\
\text { Bronchospasm }\end{array}$ & $\begin{array}{l}3 / 12 \\
1 / 12 \\
6 / 12 \\
3 / 12 \\
2 / 12 \\
1 / 12\end{array}$ & $\begin{array}{r}25 \\
8 \\
50 \\
25 \\
17 \\
8\end{array}$ & $\begin{array}{r}5-58 \\
0-39 \\
21-79 \\
5-58 \\
2-49 \\
0-39\end{array}$ \\
\hline $\begin{array}{l}\text { Circula- } \\
\text { tion: }\end{array}$ & $\begin{array}{l}\text { Tachycardia } \\
\text { Hypertension } \\
\text { Hypotension }\end{array}$ & $\begin{array}{r}10 / 12 \\
6 / 12 \\
0 / 12\end{array}$ & $\begin{array}{r}83 \\
50 \\
0\end{array}$ & $\begin{array}{r}51-98 \\
21-79 \\
0-27\end{array}$ \\
\hline $\begin{array}{l}\text { Abdo- } \\
\text { men: }\end{array}$ & $\begin{array}{l}\text { Nausea } \\
\text { Metallic taste } \\
\text { Salivation }\end{array}$ & $\begin{array}{l}1 / 12 \\
4 / 12 \\
0 / 12\end{array}$ & $\begin{array}{r}8 \\
33 \\
0\end{array}$ & $\begin{array}{l}0-39 \\
9-66 \\
0-27\end{array}$ \\
\hline $\begin{array}{l}\text { CNS and } \\
\text { ANS: }\end{array}$ & $\begin{array}{l}\text { Headache } \\
\text { Outbreak of sweat } \\
\text { "Wet eyes", tears } \\
\text { Agitation } \\
\text { Congestion of head }\end{array}$ & $\begin{array}{l}5 / 12 \\
1 / 12 \\
5 / 12 \\
2 / 12 \\
0 / 12\end{array}$ & $\begin{array}{r}42 \\
8 \\
42 \\
17 \\
0\end{array}$ & $\begin{array}{r}15-73 \\
0-39 \\
15-73 \\
2-49 \\
0-27\end{array}$ \\
\hline $\begin{array}{l}\text { Treat- } \\
\text { ment: }\end{array}$ & $\begin{array}{l}\mathrm{H}_{1} \text {-receptor antagonists } \\
\text { 6-Methylprednisolone } \\
\text { Epinephrine }\end{array}$ & $\begin{array}{l}2 / 12 \\
1 / 12 \\
0 / 12\end{array}$ & $\begin{array}{r}17 \\
8 \\
0\end{array}$ & $\begin{array}{l}2-49 \\
0-39 \\
0-27\end{array}$ \\
\hline
\end{tabular}

Each symptom was recorded only once in a single volunteer. $\mathrm{n}_{1}=$ number of subjects showing the symptom, $n_{2}=$ number of subjects showing the anaphylactoid response

The more long-lasting elevation of plasma histamine levels in histamine-release responses than after histamine injection was remarkable, but could easily be explained in terms of pharmacokinetics by a longer invasion time. Finally, in none of the 3 volunteers hypotensive reactions occurred, but only slight hypertensive responses.

The incidence ratio of pathological plasma histamine levels and clinical signs of an anaphylactoid reaction varied again from indicant to indicant (Table 4). Tachycardia was again the most frequent clinical symptom of an anaphylactoid reaction. Hypertension, but not hypotension was observed at these plasma histamine levels. Once recognized as a typical histamine effect (Table 3) the "metallic" taste was also reported by the volunteers, headache, wet eyes or tears were also observed in about half of the subjects. Treatment was necessary in two of the volunteers (No. 21 and 33 in Fig. 5), an indicant which was rather complex and contained all the judgements of the two anaesthesiologists in the team. However, no emergency treatment was necessary in any of the volunteers.

Several remarkable differences, however, were observed between histamine injection and histamine release by polygeline despite the finding that the average plasma histamine 
Table 5. Incidence ratio for pathological plasma histamine levels and clinical signs in allergoid (cutaneous anaphylactoid) reactions of conscious volunteers and orthopedic patients following infusion of polygeline

\begin{tabular}{|c|c|c|c|}
\hline \multirow[t]{2}{*}{ Symptom or indicant } & \multicolumn{3}{|c|}{ Incidence } \\
\hline & $n_{1} / n_{2}$ & $\%$ & $\begin{array}{l}95 \% \\
\text { confi- } \\
\text { dence } \\
\text { interval }\end{array}$ \\
\hline
\end{tabular}

a) volunteers

\begin{tabular}{|c|c|c|c|c|}
\hline \multicolumn{2}{|c|}{ Plasma histamine level $>1 \mathrm{ng} / \mathrm{ml}$} & $\begin{array}{l}0 / 11 \\
1 / 11\end{array}$ & $\begin{array}{l}0 \\
9\end{array}$ & $\begin{array}{l}0-29 \\
0-42\end{array}$ \\
\hline Skin: & $\begin{array}{l}\text { Flush } \\
\text { Erythema } \\
\text { Wheals and papules } \\
\text { Pruritus }\end{array}$ & $\begin{array}{r}1 / 11 \\
2 / 11 \\
10 / 11 \\
5 / 11\end{array}$ & $\begin{array}{r}9 \\
18 \\
91 \\
45\end{array}$ & $\begin{array}{c}0-42 \\
2-52 \\
58-100 \\
16-77\end{array}$ \\
\hline $\begin{array}{l}\text { Respir. } \\
\text { tact: }\end{array}$ & Sneezing & $2 / 11$ & 18 & $2-52$ \\
\hline $\begin{array}{l}\text { Abdo- } \\
\text { men }\end{array}$ & $\begin{array}{l}\text { Metallic taste } \\
\text { Swelling of parotid gland }\end{array}$ & $\begin{array}{l}2 / 11 \\
1 / 11\end{array}$ & $\begin{array}{r}18 \\
9\end{array}$ & $\begin{array}{l}2-52 \\
0-42\end{array}$ \\
\hline \multicolumn{5}{|c|}{ b) patients } \\
\hline \multicolumn{2}{|c|}{ Plasma histamine level $>1 \mathrm{ng} / \mathrm{ml}$} & $2 / 96$ & 2 & $0-7$ \\
\hline Skin: & $\begin{array}{l}\text { Flush } \\
\text { Erythema } \\
\text { Wheals and papules } \\
\text { Pruritus }\end{array}$ & $\begin{array}{r}2 / 96 \\
10 / 96 \\
90 / 96 \\
11 / 96\end{array}$ & $\begin{array}{r}2 \\
10 \\
94 \\
11\end{array}$ & $\begin{array}{r}0-7 \\
5-18 \\
89-98 \\
5-19\end{array}$ \\
\hline $\begin{array}{l}\text { Respir. } \\
\text { tract: }\end{array}$ & Sneezing & $0 / 96$ & 0 & $4-4$ \\
\hline $\begin{array}{l}\text { Abdo- } \\
\text { men: }\end{array}$ & $\begin{array}{l}\text { Metallic taste } \\
\text { Sweeling of parotid gland }\end{array}$ & $\begin{array}{l}0 / 96 \\
1 / 96\end{array}$ & $\begin{array}{l}0 \\
1\end{array}$ & $\begin{array}{l}0-4 \\
0-5\end{array}$ \\
\hline
\end{tabular}

Each symptom was recorded only once in a single patient. $\mathrm{n}_{1}=$ number of patients with the particular indicant

$\mathrm{n}_{2}=$ number of patients with allergoid reaction

No tachycardia, no change in blood pressure was observed in any of the subjects following polygeline infusion

levels were quite similar in these two conditions. Flush and erythema were rather rare. Hives (wheals) were more frequent, but had to be searched for by very careful inspection of the whole body. Sneezing, narrowness of the throat and cough were the most common respiratory symptoms, but could not be imitated by histamine injection (Table 3).

In the volunteer study 11 subjects showed an allergoid reaction and 17 individuals were non-responders. Pathological plasma histamine levels exceeding $1 \mathrm{ng} / \mathrm{ml}$ were observed in none of them (Table 5). Wheals and papules were the only indicants with an incidence ratio of more than $50 \%$ in volunteers with allergoid reactions.

\section{Plasma Histamine Levels and Clinical Signs in Orthopedic Patients Following Infusion of Polygeline}

An anaphylactoid reaction was observed in 30 patients corresponding to $5 \%$ in the whole trial of 600 subjects. 3 of them were life-threatening (Fig. 6) corresponding to $0.5 \%$. Reactions of such a severity had never been elicited in volunteers [34-36]. In 26 of the patients plasma histamine levels of more than $1 \mathrm{ng} / \mathrm{ml}$ were determined (Fig. 7), 4 of them were test-negative. The average plasma histamine level was $2.4 \mathrm{ng} / \mathrm{ml}$ which compares well with the $1.9 \mathrm{ng} / \mathrm{ml}$ in
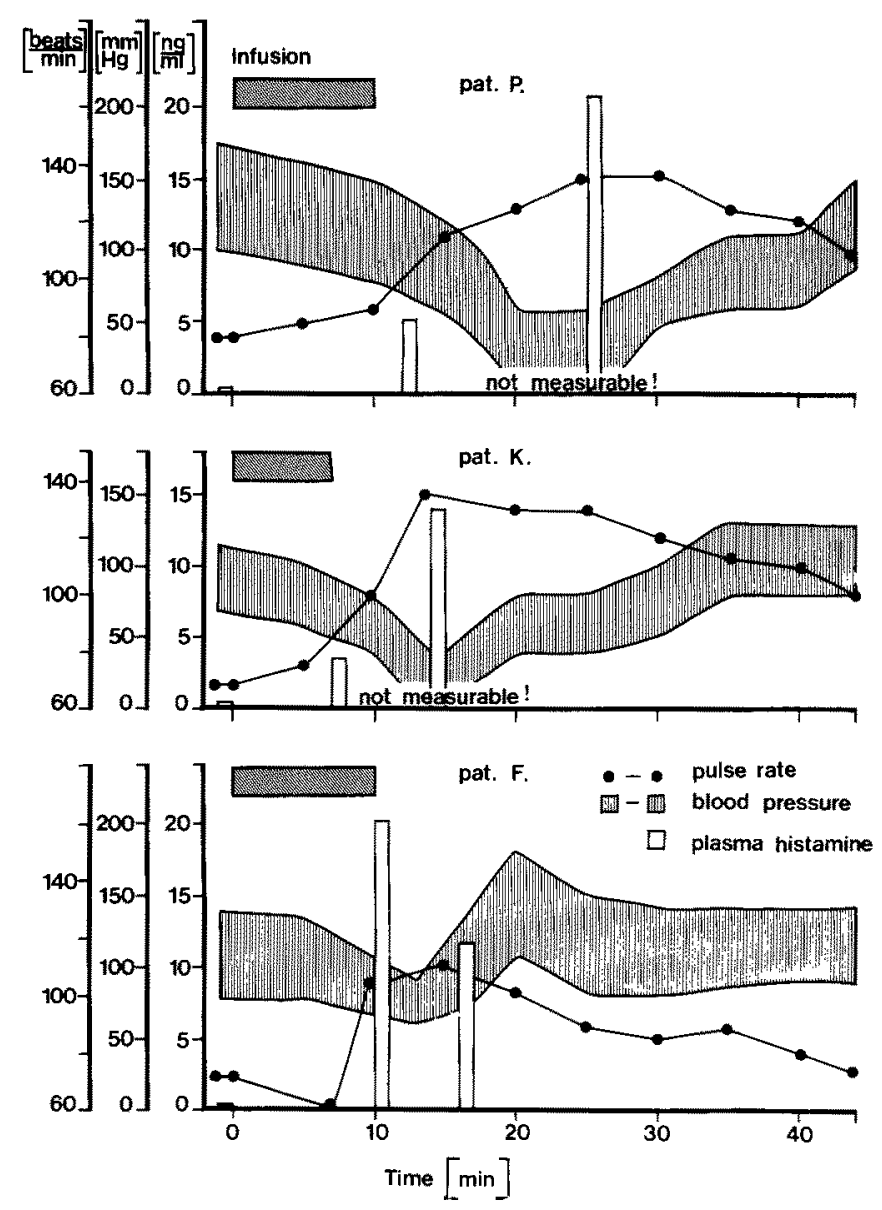

Fig. 6. Life-threatening anaphylactoid reactions to polygeline in the clinical trial in orthopedic patients. Single values from each of the patients. In the first patient (P) the second blood sample was taken $2 \mathrm{~min}$ after the end of infusion and the third one $13 \mathrm{~min}$ later. This exception from the protocol was caused by treatment of the patient. The attributes of the 3 patients were not especially different from those of the others in trial: Patient P.I. (65 years, male, $90 \mathrm{~kg}$, Bohemian farmer, no history of allergy, received $500 \mathrm{ml}$ polygeline in $10 \mathrm{~min}$ (V265) without previous exposure to the drug). Patient $\mathrm{K} . \mathrm{Ph}$. (43, male, 80 , South German industrial worker, allergy against penicillin) received $500 \mathrm{ml}$ (V265) in $8 \mathrm{~min}$ without previous exposure to the drug. Patient F.W. (50, male, 72 , South German civil servant, no allergy) received $450 \mathrm{ml}$ (V244) in $10 \mathrm{~min}$ without previous exposure to polygeline

the volunteer study. The variation of the values $(0.6-20 \mathrm{ng} /$ $\mathrm{ml})$, however, was greater than in volunteers after injection of histamine or infusion of polygeline. The pathological plasma histamine levels were not normally distributed and were not correlated to the basal plasma histamine levels (Fig. 7). Thus by measuring basal plasma histamine concentrations before infusion responders and non-responders to polygeline could not be predicted.

The incidence ratio of pathological plasma histamine levels and clinical signs of an anaphylactoid reaction varied from indicant to indicant as it was found in volunteers (Table 6). Tachycardia was again the most frequent symptom, erythema, wheals and cough had a high, flush only a medium and hypotension, nausea and outbreak of sweat a low incidence. It should be emphasized that hypotension as a classical histamine reaction is of very minor importance in diagnosing an average histamine-release response. 


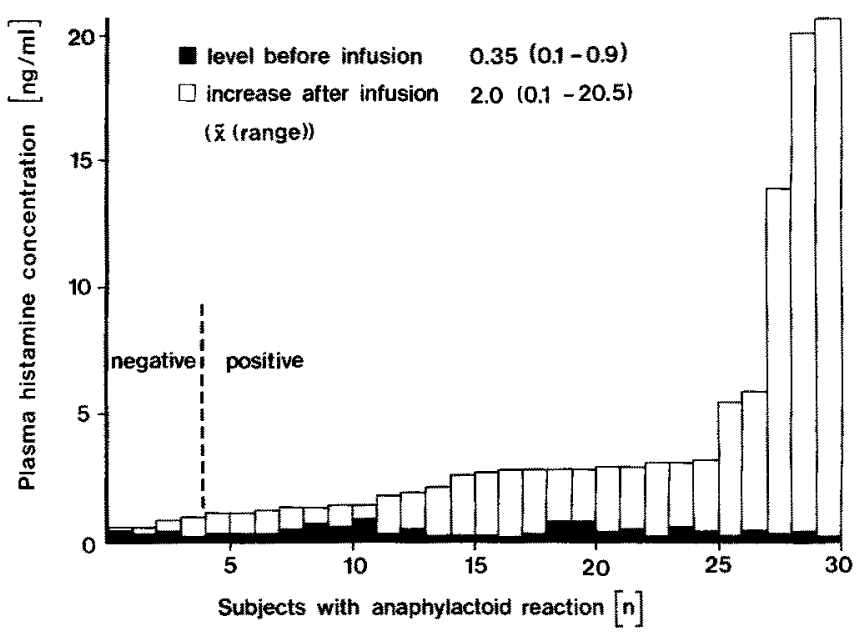

Fig. 7. Plasma histamine levels before and after infusion of polygeline in patients with an anaphylactoid reaction. Single values obtained from each of the patients. The vertical doted line indicates the cut-off point for a pathological plasma histamine level

Table 6. Incidence ratio for pathological plasma histamine levels and clinical signs in anaphylactoid reactions of conscious orthopedic patients

\begin{tabular}{|c|c|c|c|c|}
\hline \multicolumn{2}{|c|}{ Symptom or indicant } & \multicolumn{3}{|c|}{ Incidence } \\
\hline & & $n_{1} / n_{2}$ & $\%$ & $\begin{array}{l}95 \% \\
\text { confi- } \\
\text { dence } \\
\text { interval }\end{array}$ \\
\hline \multicolumn{2}{|c|}{ Plasma histamine level $>1 \mathrm{ng} / \mathrm{ml}$} & $26 / 30$ & 87 & $70-96$ \\
\hline Skin: & $\begin{array}{l}\text { Flush } \\
\text { Erythema } \\
\text { Wheals } \\
\text { Facial oedema }\end{array}$ & $\begin{array}{r}13 / 30 \\
21 / 30 \\
18 / 30 \\
9 / 30\end{array}$ & $\begin{array}{l}43 \\
70 \\
60 \\
30\end{array}$ & $\begin{array}{l}24-64 \\
52-84 \\
40-77 \\
16-48\end{array}$ \\
\hline $\begin{array}{l}\text { Respiratory } \\
\text { tract: }\end{array}$ & $\begin{array}{l}\text { Sneezing } \\
\text { Stoffy nose } \\
\text { Narrowness of throat } \\
\text { Coughing } \\
\text { Respiratory distress } \\
\text { Bronchospasm }\end{array}$ & $\begin{array}{r}7 / 30 \\
9 / 30 \\
3 / 30 \\
15 / 30 \\
5 / 30 \\
1 / 30\end{array}$ & $\begin{array}{r}23 \\
30 \\
10 \\
50 \\
17 \\
3\end{array}$ & $\begin{array}{r}10-41 \\
16-48 \\
2-25 \\
32-68 \\
6-33 \\
0-17\end{array}$ \\
\hline Circulation: & $\begin{array}{l}\text { Tachycardia } \\
\text { Hypotension }\end{array}$ & $\begin{array}{r}28 / 30 \\
3 / 30\end{array}$ & $\begin{array}{l}93 \\
10\end{array}$ & $\begin{array}{r}79-99 \\
2-25\end{array}$ \\
\hline Abdomen: & $\begin{array}{l}\text { Nausea } \\
\text { Vomiting } \\
\text { Abdominal pain }\end{array}$ & $\begin{array}{l}7 / 30 \\
2 / 30 \\
1 / 30\end{array}$ & $\begin{array}{r}23 \\
7 \\
3\end{array}$ & $\begin{array}{r}10-41 \\
1-21 \\
0-17\end{array}$ \\
\hline $\begin{array}{l}\text { CNS and } \\
\text { vegetative } \\
\text { nervous } \\
\text { system: }\end{array}$ & $\begin{array}{l}\text { Headache } \\
\text { Outbreak of sweat } \\
\text { Tears } \\
\text { Agitation }\end{array}$ & $\begin{array}{l}1 / 30 \\
1 / 30 \\
1 / 30 \\
3 / 30\end{array}$ & $\begin{array}{r}3 \\
3 \\
3 \\
10\end{array}$ & $\begin{array}{l}0-17 \\
0-17 \\
0-17 \\
2-25\end{array}$ \\
\hline Treatment: & $\begin{array}{l}\mathrm{H}_{1} \text {-receptor antagonists } \\
\text { 6-Methylprednisolone } \\
\text { Stop of infusion } \\
\text { Infusion } \\
\text { Oxygen } \\
\text { Epinephrine }\end{array}$ & $\begin{array}{r}23 / 30 \\
6 / 30 \\
8 / 30 \\
3 / 30 \\
1 / 30 \\
1 / 30\end{array}$ & $\begin{array}{r}77 \\
20 \\
27 \\
10 \\
3 \\
3\end{array}$ & $\begin{array}{r}59-90 \\
9-37 \\
13-44 \\
2-25 \\
0-17 \\
0-17\end{array}$ \\
\hline
\end{tabular}

Each symptom was recorded only once in a single patient. $\mathrm{n}_{1}=$ number of subjects showing the symptom, $\mathrm{n}_{2}=$ number of subjects showing the anaphylactoid reaction
Agreement in the incidence ratio of indicants between the 3 investigated conditions was very satisfactory for some of the symptoms, such as pathological plasma histamine level, tachycardia, flush, hypotension, nausea, and outbreak of sweat (Table 3, 4 and 6). More interesting however, were the many disagreements. We should not underestimate the series with histamine injection as a rather artificial condition since histamine release may not always occur in the skin, but also selectively in the liver, the gut, the lungs or in other tissues with large histamine stores, and histamine may enter the circulation just in the way of a protracted histamine injection. The different incidences of symptoms between histamine injection (Table 3 ) and histamine-release (Tables 4 and 6) include those of wheals, facial oedema and rather all respiratory symptoms. All these symptoms can be explained by very high local concentrations of free histamine due to mast cell degranulation within the effector tissue and could therefore not be imitated by a systemic histamine injection.

Other differences, however, in the incidence ratio of symptoms pointed to a considerable observer variation despite the effort made to diminish it (see Methods). "Metallic taste" was a frequent symptom in volunteers, but absent in patients. Retrolective assessment revealed that the question had been asked in patients as "irritation of taste". By this type of a question it was probably missed. Headache and "wet eyes" or tears were not asked about or looked for in patients at all in the operation theatre. Observer variation was by no means unique to the present study, but is well known to occur in general in clinical trials $[8,16$, 43].

Since some higher plasma histamine levels were observed in patients than in volunteers more serious symptoms, such as respiratory distress and bronchospasm, hypotension, vomitting and abdominal cramps and the necessity for emergency treatment were observed (Fig. 8). Thus these severe adverse responses to polygeline could be used to define life-threatening histamine release response. In addition, a significant correlation was detected between the increase in pulse rate and the increase in plasma histamine levels (Fig. 9.). This correlation was slightly higher when absolute plasma histamine levels were encountered then when increases in plasma histamine concentrations were used. Thus tachycardia was not only the symptom with the highest incidence ratio, but also the parameter which best was correlated with the plasma histamine levels.

As in volunteers also in patients for diagnosing an allergoid reaction only wheals and papules showed a high incidence ratio (Table 5). Pathological plasma histamine levels were measured only in two of the subjects. In all other cases the plasma histamine concentration remained within the normal range and did not differ significantly from the pre-infusion levels (Fig. 10). They were similar in patients with single or in those with many wheals, in patients with hives in one body region or in more than one. In particular, they were not significantly different from those in patients without any detectable reaction.

\section{Decision-making Matrix for Diagnosing an Anaphylactoid Reaction to Polygeline by Pathological Plasma Histamine Levels}

The previous parts of Results were concentrated on the incidence ratios of pathological plasma histamine levels and 

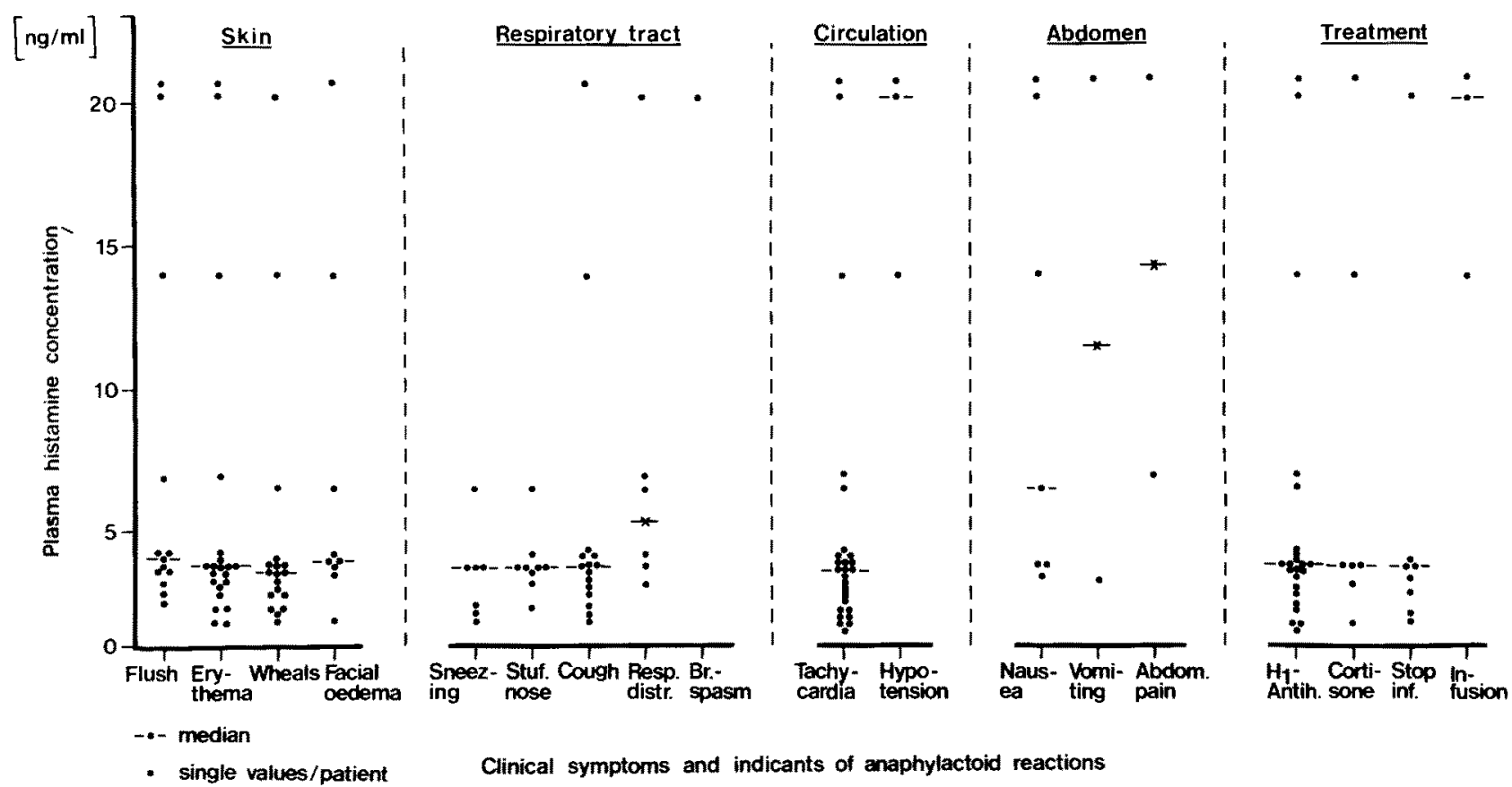

Fig. 8. Plasma histamine levels and clinical signs of an anaphylactoid reaction to polygeline in conscious orthopedic patients. Each symptom and plasma histamine level were recorded only once in a single volunteer. $n=30$. For abbreviations of symtpoms use Tables $3-5$ and Appendix 1 of this communication

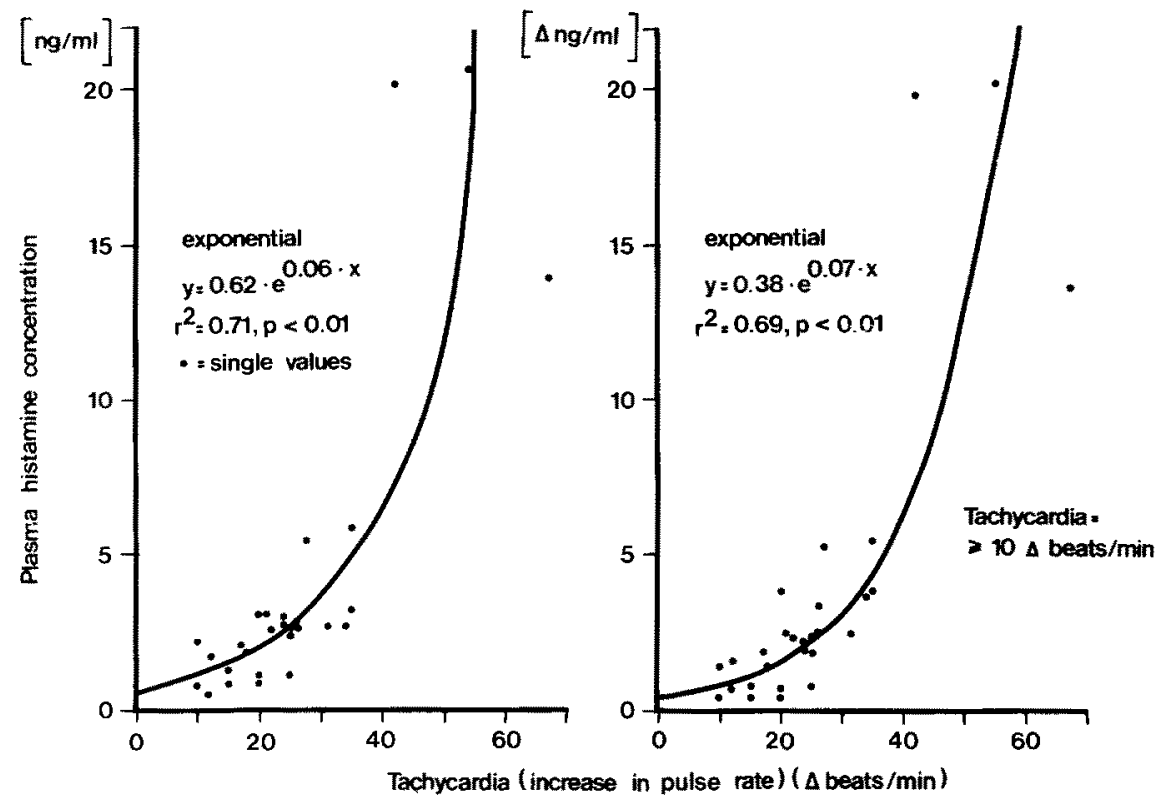

Fig. 9. Correlation between increase in pulse rate and plasma histamine levels in patients with an anaphylactoid reaction to polygeline. Single values from each of the patients with systemic response. Left side: Absolute plasma histamine concentration. Right side: Increase in plasma histamine levels clinical signs in anaphylactoid reactions to histamine and polygeline. One of these indicants to be used for diagnosing an anaphylactoid reaction was analysed in a decision-making matrix for sensitivity, specificity and efficiency: the plasma histamine level (Fig. 11).

As expected for this case with a predominant histamine releaser, the plasma histamine assay was a highly efficient test for diagnosing a systemic anaphylactoid reaction. Many other "potent" diagnostic tools such as endoscopy and X-rays in peptic ulcer or measurement of plasma catecholamines in pheochromocytoma do not achieve more satisfactory results.

\section{Discussion}

The main aim of this study was to establish the diagnosis of a histamine-release response to an individual drug in an individual patient. One of the strategies for solving this problem is conducted in two steps: (1) Subjects with the disease and without the disease were selected by previously accepted criteria and indicants (case history data, clinical signs, laboratory tests etc) were collected by which these groups of subjects could be best discriminated. (2) Incidence ratios and conditional probabilities (e.g. sensitivity, specificity) for these indicants were calculated [43] and those 


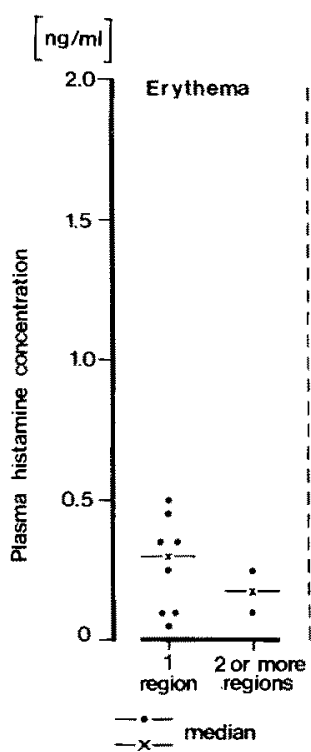

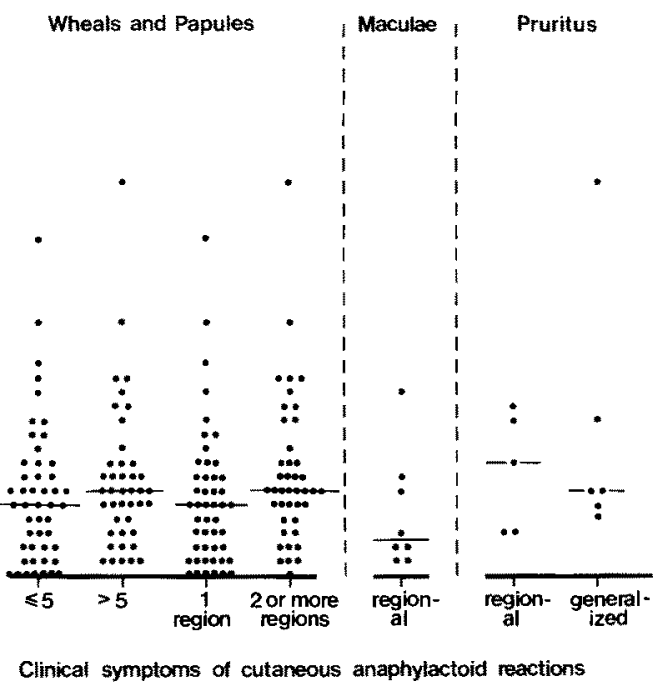

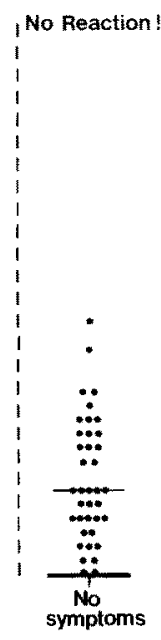

Fig. 10. Plasma histamine levels and clinical signs of an allergoid (cutaneous anaphylactoid) reaction to polygeline in conscious orthopedic patients. For conditions of assessment see Fig. 8. $n=$ 96 for cutaneous reactions, $n=38$ for control patients without any reaction (see also Table 2) a) Systeaic reoction versus non-responders

\begin{tabular}{|c|c|c|c|}
\hline \multirow[b]{2}{*}{ Test result } & \multicolumn{3}{|c|}{ Disease status } \\
\hline & SAR & No SAR & Totals \\
\hline PHL $>1 \mathrm{ng} / \mathrm{ml}$ & 26 & 0 & 26 \\
\hline $\mathrm{PHL} \leqslant 1 \mathrm{ng} / \mathrm{ml}$ & 4 & 38 & 42 \\
\hline Totals & 30 & 38 & 68 \\
\hline $\begin{array}{l}\text { iensitivity } \frac{26}{30}= \\
\text { fficiency } \frac{64}{68}=\end{array}$ & $\psi_{i}$ & fint tot & $\frac{38}{38}=100$ \\
\hline
\end{tabular}

b) Systemic reaction versus cutaneous reaction

\begin{tabular}{|l|c|c|c|}
\hline & \multicolumn{3}{|c|}{ Di sease status } \\
Test result & SAR & No SAR & Totals \\
\hline PHL $>1 \mathrm{ng} / \mathrm{mI}$ & 26 & 2 & 28 \\
\hline $\begin{array}{l}\text { PHL } \leqslant 1 \mathrm{ng} / \mathrm{mI} \\
\text { Totals }\end{array}$ & 4 & 94 & 98 \\
\hline
\end{tabular}

Sensitivity $87 \%$, specificity $98 \%$, efficiency $95 \%$

Fig. 11. Diagnostic decision-making matrix for plasma histamine level (test result) and systemic anaphylactoid reaction (disease status). Two possibilities are shown for diagnosing a systemic anaphylactoid reaction $(S A R)$ : One in contrast to non-response and one in contrast to cutaneous response which is also a non-response as far as a systemic response is concerned. $P H L=$ plasma histamine level. For further information see $[43,68]$

which are the most satisfactory predictors [15] were chosen for defining and classifying the disease $[43,71]$. The definition of the disease "histamine-release response" is based on symptoms and tests (accessible characteristics of the disease according to Wulff [71], but it is also causally defined. This is one of the main advantages of this disease definition compared to the term "anaphylactoid reaction" which by far is more a syndrome [12] than a causally defined disease.
Table 7. Indicants with highest incidence ratio in a systemic anaphylactoid reaction (SAR) in conscious human subjects

\begin{tabular}{|c|c|c|}
\hline $\begin{array}{l}\text { Group of } \\
\text { subjects }\end{array}$ & Indicants for SAR & $\begin{array}{l}\text { Incidence } \\
\text { ratio }[\%]\end{array}$ \\
\hline $\begin{array}{l}\text { Volunteers } \\
\text { after i.v. } \\
\text { histamine } \\
\text { injection }\end{array}$ & $\begin{array}{l}\text { Tachycardia } \\
\text { Plasma histamine }>1 \mathrm{ng} / \mathrm{ml} \\
\text { "Metallic" taste } \\
\text { Flush } \\
\text { Congestion of head } \\
\text { "Wet eyes", tears } \\
\text { Hypertension } \\
\text { Headache }\end{array}$ & $\begin{array}{l}97 \\
78 \\
75 \\
69 \\
67 \\
64 \\
58 \\
58\end{array}$ \\
\hline $\begin{array}{l}\text { Volunters } \\
\text { with SAR } \\
\text { following } \\
\text { Haemaccel }\end{array}$ & $\begin{array}{l}\text { Plasma histamine }>1 \mathrm{ng} / \mathrm{ml} \\
\text { Tachycardia } \\
\text { Wheals } \\
\text { Sensation of heat } \\
\text { Narrowness of throat } \\
\text { Hypertension } \\
\text { Headache } \\
\text { "wet eyes", tears }\end{array}$ & $\begin{array}{l}93 \\
83 \\
58 \\
50 \\
50 \\
50 \\
42 \\
42\end{array}$ \\
\hline $\begin{array}{l}\text { Patients } \\
\text { with SAR } \\
\text { following } \\
\text { Haemaccel }\end{array}$ & $\begin{array}{l}\text { Tachycardia } \\
\text { Plasma histamine }>1 \mathrm{ng} / \mathrm{ml} \\
\text { Erythema } \\
\text { Wheals } \\
\text { Cough } \\
\text { Flush } \\
\text { Stuffy nose } \\
\text { Facial oedema }\end{array}$ & $\begin{array}{l}93 \\
87 \\
70 \\
60 \\
50 \\
43 \\
30 \\
30\end{array}$ \\
\hline
\end{tabular}

Values taken from Tables 3,4 and 6. Tachycardia =increase in heart and pulse rate/min resp. by more than 5 beats/min. Changes in blood pressure $=$ increase or decrease by more than $10 \mathrm{~mm} \mathrm{Hg}$ (systolic)

The indicants with the highest incidence ratio in the 3 conditions investigated were compiled in Table 7. Despite observer vatiation and different techniques for elevating the plasma histamine concentration there were marked similarities in the incidence ratio of several predictors: Tachycardia and plasma histamine levels $>1 \mathrm{ng} / \mathrm{ml}$ showed a very high incidence. Single wheals or a few of them and spots of erythema which have to be meticulously looked for (Fig. 10) 
occurred frequently following histamine release by polygeline (see also $[35,55]$ ) and "narrowness of throat" and "cough" were frequent symptoms in either the one or the other group of subjects which probably have the same pathological substrate: histamine release and oedema in the laryngeal region. Other symptoms showed a variable incidence ratio in between the studies such as hypertension, "wet eyes" and tears, and headache, but this negative finding very probably can be changed by reducing observer variation [16]. Finally clinical symptoms originating from nasal mucosa, such as sneezing, stoffy nose, nasal catarrh etc. occur in about one-third of the cases and should probably included in the definition of a systemic anaphylactoid reaction.

Following the course of discussion it is now necessary to define an average histamine-release response in a more extended manner than in the section of Statistics and Definitions. In part, the term "average" has a statistical meaning indicating the most frequent grade of severity of an anaphylactoid reaction observed in clinical conditions. In part, the term is a judgement since it does not include cutaneous anaphylactoid reactions which by far are more frequent than systemic reactions. Thus an average histaminerelease response is always a systemic histamine-release response and as such a special case of an anaphylactoid reaction $[12,22,39]$. It is restricted to a syndrome in which histamine is the predominant mediator. For this reason in man the anaphylactoid reaction elicited by dextran and probably also by some other plasma substitutes [52] is not a histamine-release response, but may be an SRS-A or kinin-formation response. These examples should demonstrate that controlled clinical trials in combination with methods of medical decision making may help to find the specific "quantitative spectrum" of signs, symptoms and biological reactions elicted by other mediators involved in anaphylactic and pseudo-allergic reactions. Serotonin, kinins, leukotrienes, prostaglandins all cause similar symptoms in man, but who ever knows whether these symptoms occur with the same incidence or have the same conditional probabilities as in a systemic histamine-release response? Thus medical-decision making may help to differentiate adverse drug reactions and constitute a new approach to their more successful prophylaxis and treatment.

Using the indicants in Table 7 an average histaminerelease response is a systemic anaphylactoid reaction which is characterized by clinical signs, such as tachycardia and mild hypertension, scattered hives such as spots of erythema and wheals, respiratory symptoms in the laryngeal and nasal region such as cough, narrowness in the throat, tuffy nose and sneezing and pathological plasma histamine levels $(>1 \mathrm{ng} / \mathrm{ml})$.

The classical symptoms of an "anaphylactic" reaction $[3,61]$, such as hypotension, bronchospasm, and extended reactions in the skin with erythema or wheals covering large areas of the body are found only in $10 \%$ of systemic histamine-release responses. However, they are of great clinical importance for the life of patients and must not be underestimated by the new definition of an average histamine-release response. Also cutaneous reactions are not negligible events since they can indicate severe incidents in a second exposure to the drug [66] and may be associated with pathological processes such as platelet aggregation [69] or coagulation disturbances [61] which hitherto have never been studied in volunteers or in patients.
Table 8. Classification of histamine-release responses by severity

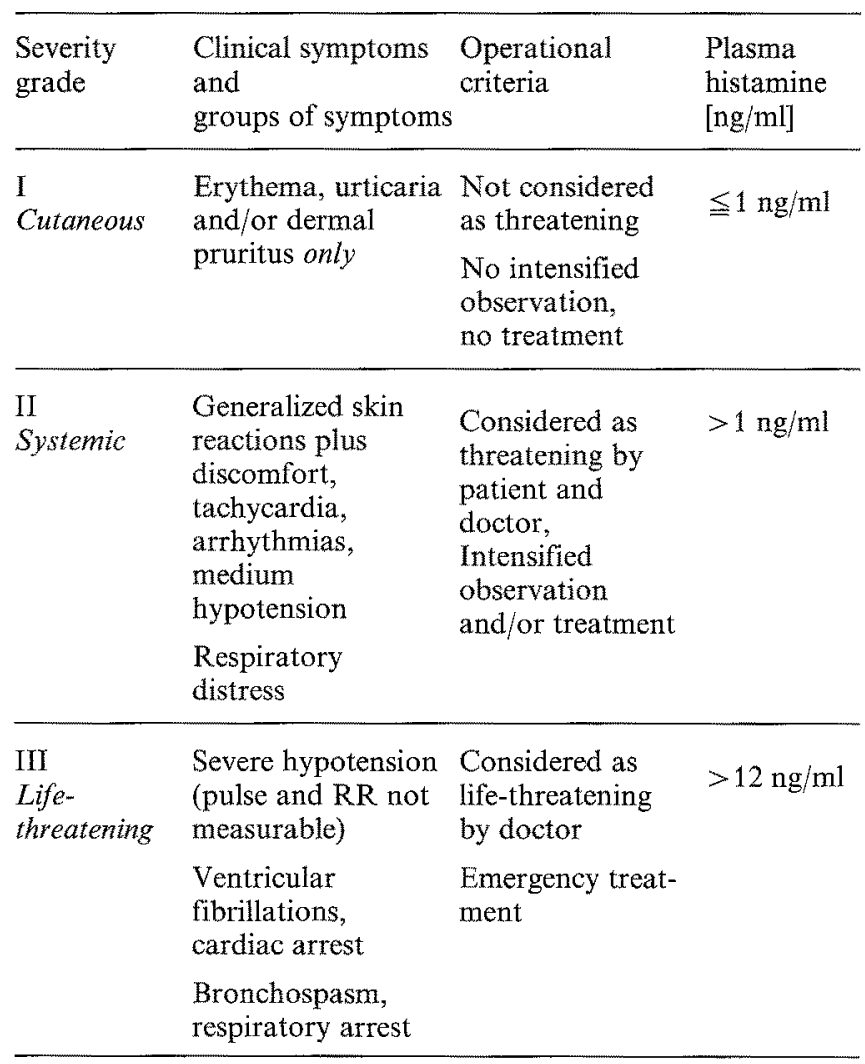

For these reasons a classification of histamine-release responses by severity is necessary (Table 8 ). The limit for a plasma histamine level between a systemic and a lifethreatening reaction was taken from the 3 severe incidents in the polygeline trial in patients. This classification, however, is supported by plasma histamine values obtained in life-threatening reactions to anaesthetic agents [28]. Cutaneous histamine-release responses in general can be more accurately diagnosed by measuring histamine content in the blister fluid [21] if wheals occur in an individual patient, but this has not yet been worked out systematically. For polygeline, however, also cutaneous anaphylactoid reactions can be denoted as cutaneous histamine-release responses since by $\mathrm{H}_{1}$ - and $\mathrm{H}_{2}$-receptor antagonists it has been shown that histamine was the predominant mediator also in these kind of reactions $[35,55]$.

The definition of a histamine-release response by plasma histamine levels implicates a time problem. The velocity of plasma histamine increment shortly after drug application is explosive and the subsequent elimination is very fast, especially in cases with plasma histamine levels not higher than $5 \mathrm{ng} / \mathrm{ml}$. Thus a histamine-release response can be defined quite easily [36, 39], but diagnosed reliably in an individual patient only if the blood samples were taken near or at the time of maximum response. It has been shown that the severity of the most striking symptoms, especially those in the circulatory system, run parallel to the kinetics of the plasma histamine levels [28, 34].

Adverse reactions which mimic the symptoms of anaphylaxis were denoted as anaphylactoid or as pseudo-allergic reactions $[12,22,39,64]$. Since histamine in experimental animals $[17,47,53,70]$ and in human subjects under 
certain circumstances elicits the 3 classical symptoms of anaphylaxis it was thought that histamine-release response should be diagnosed and defined by these symptoms or by some less severe variations of these symptoms. However, this communication illustrates by one intensely studied example with one clinically used histamine releaser (experiments in animals and human subjects for more than 10 years [29-32, 34, 39, 40, 44, 54] that the classical symptoms of anaphylaxis are rare in histamine-release responses in general and only more common ("classical") in grade III reactions. Increasing experience, however, in animals [6, $25,42,49,50,60$ ] and in man [61] is forming the suggestion that even this may not be true: Clinical pictures of severe heart attack or arrhythmias may be caused by histaminerelease responses which clearly have to be classified as grade III reactions.

Thus the highly controversial discussions about the incidences of adverse reactions to drugs which release histamine in man (for a survey see $[2,7,11,14,39,40,52,65,67]$ can probably procede to a considerable agreement if techniques of controlled trials [19] were combined with decision-making procedures to solve this problem. It is a classical task of medical-decision making to "use the diagnostic information to revise probabilities [68] or in other words to revise the figures for the incidences of adverse drug reactions.

Acknowledgement. The authors are very grateful to the constructive criticism of this manuscript given by H. Immich, M.J.R. Healy, J. Watkins and L. Lusted. They are very grateful to B. Schwarz, D. Weber, E. Hinterlang and M. Verfürth for their skilful technical assistence, drawing of figures and the careful typing of this communication. In addition, the improvement of the English by J.V. Parkin (London) is very appreciated.

\section{References}

1. Adelmann B, Schöning B (1980) Binding of native and denaturated collagen to immunoglobulins and cold insoluble globulin in serum of patients undergoing orthopaedic surgery. Klin Wochenschr 58:625-629

2. Ahnefeld FW, Fischer F, Frey R, Kilian J, Schöning B (1979) Der Infusionszwischenfall nach künstlichen Plasmasubstituten im Meldekollektiv der Arzneimittelkommission. Anaesthesist 28:207-220

3. Austen KF (1974) Systemic anaphylaxis in the human being. New Engl J Med 291:661-664

4. Beaven MA, Jacobsen S, Horáková Z (1972) Modification of the enzymatic isotopic assay of histamine and its application to measurement of histamine in tissues, serum and urine. Clin Chim Acta 37:91-103

5. Black JW, Duncan WAM, Durant CJ, Ganellin CR, Parsons EM (1972) Definition and antagonism of histamine $\mathrm{H}_{2}$-receptor. Nature 236:385-390

6. Bristow MR, Sageman WS, Scott RH, Billingham ME, Bowden RE, Kernoff RS, Snidow GH, Daniels JR (1980) J Cardiovasc Pharmacol 2:487-515

7. Clarke RSJ, Dundee JW (1981) Adverse reactions to intravenous induction agents. In: Thornton JA (ed) Adverse reactions to anaesthetic drugs. Excerpta Medica/Elsevier North Holland, Amsterdam, pp 29-46

8. de Dombal FT, Staniland JR, Clamp SE (1981) Geographical variation in disease presentation. Does it constitute a problem and can information science help? Med Decis Making 1:59-69

9. Doenicke A, Lorenz W (1970) Histaminfreisetzung und anaphylaktoide Reaktionen bei Narkosen. Biochemische und klinische Aspekte. Anaesthesist 19:413-417

10. Doenicke A, Lorenz W, Beigl R, Bezecny H, Uhlig G, Kalmar
L, Praetorius B, Mann G (1973) Histamine release after intravenous application of short-acting hypnotics: a comparison of etomidate, althesin (CT 1341) and propanidid. Br J Anaesthesia 45:1097-1104

11. Doenicke A (1975) Propanidid. In: Arias A, Llaurado R, Nalda MA, Lunn JN (eds) Proc. IV. Europ. Congr. Anesthesiology. Excerpta Medica, Amsterdam, pp 107-113

12. Dukor P, Kallós P, Schlumberger HD, West GB (1980) Genetic aspects and anaphylactoid reactions. in: PAR. Pseudo-allergic reactions. Involvement of drugs and chemicals, vol 1. Karger, Basel, pp 1-307

13. Editorial (1981) Histamine and antihistamines in anaesthesia and surgery. Lancet $2: 74-75$

14. Fisher MMCD (1979) Intradermal testing in the diagnosis of acute anaphylaxis during anaesthesia - results of five years experience. Anaesthesiol Intens Care 7:58-61

15. Galen RS, Gambino SR (1975) Beyond normality: the predictive value and efficiency of medical diagnoses. Wiley \& Sons, New York, pp 1-185

16. Gill PW, Leaper DJ, Guillou PJ, Staniland JR, Horrocks JC, de Dombal FT (1973) Observer variation in clinical diagnosis - a computer aided assessment of its magnitude and importance in 552 patients with abdominal pain. Meth Inform Med 12:108-113

17. Goth A (1972) Histamine release by drugs and chemicals. In: Schachter M (ed) Histamine and antihistaminics, International Encyclopedia Pharmacology Therapy, vol 74/1. Pergamon Press, Oxford, pp 25-43

18. Healy MJR, Mitchell FL (1974) Quality control and normal values. In: Curtius $\mathrm{HCh}$, Roth $\mathrm{M}$ (eds) Clinical biochemistry. Principles and methods. de Gryter, Berlin, pp 594-617

19. Horwitz RJ, Feinstein AR (1979) Methodological standards and contradictory results in case-control research. Am J Med $66: 556-562$

20. International Federation of Clinical Chemistry (IFCC), Committee on standards: Approved recommendation (1978) on quality control in clinical chemistry, part 2. Assessment of analytical methods for routine use. J Clin Chem Biochem 18:78-88 (1980)

21. Kaplan AP, Horáková Z, Katz SI (1978) Assessment of tissue fluid histamine levels in patients with urticaria. J Allergy Clin Immunol 61:350-354

22. Kazimierczak W, Diamant B (1978) Mechanisms of histamine release in anaphylactic and anaphylactoid reactions. Progr Allergy $24: 295-365$

22 a. Kuhn TS (1970) The structure of scientific revolutions. International encyclopedia unified science, vol 2, no 2. The University of Chicago Press, Chicago London, pp 1-209

23. Lecomte J (1956) Endogenous histamine liberation in man. In: Wolstenholme GWW, O'Connor CM (eds) Ciba foundation symposium on histamine. Churchill, London, pp 173-174

24. Levey St, Jennings ER (1950) The use of control charts in the clinical laboratory. Am J Clin Pathol 20:1059-1066

25. Levi R, Zavecz JH, Lee Chi-Ho, Allan G (1979) Histaminedrug-disease interactions and cardiac function. In: Yellin TD (ed) Histamine receptors. Spectrum Publ, New York, pp 99113

25a. Levi R, Allan G (1980) Histamine-mediated cardiac effects. In: Bristow M (Ed) Drug-induced heart disease. Elsevier-North Holland, Amsterdam, pp 377-395

26. Lorenz W, Benesch L, Barth H, Matejka E, Meyer R, Kusche J, Hutzel M, Werle E (1970) Fluorometric assay of histamine in tissues and body fluids: Choice of the purification procedure and identification in the nanogram range. $\mathrm{Z}$ Anal Chem 259:94-98

27. Lorenz W, Reimann H-J, Barth H, Kusche J, Meyer R, Doenicke A, Hutzel M (1972a) A sensitive and specific method for the determination of histamine in human whole blood and plasma. Hoppe-Seyler's Z Physiol Chem 353:911-920

28. Lorenz W, Doenicke A, Meyer R, Reimann H-J, Kusche J, Barth H, Geesing H, Hutzel M, Weissenbacher B (1972 b) His- 
tamine release in man by propanidid and thiopentone: Pharmacological effects and clinical consequences. $\mathrm{Br} \mathrm{J}$ Anaesthesia $44: 355-369$

29. Lorenz W, Seidel W, Doenicke A, Tauber R, Reimann H-J, Uhlig R, Mann G, Dormann P, Schmal A, Häfner G, Hamelmann H (1974a) Elevated plasma histamine concentrations in surgery: Causes and clinical significance. Klin Wochenschr $52: 419-425$

30. Lorenz W, Thermann M, Messmer K, Schmal A, Dormann $P$, Kusche J, Barth $H$, Tauber R, Hutzel M, Mann G, Uhlig $\mathrm{R}(1974 \mathrm{~b})$ Evaluation of histamine elimination curves in plasma and whole blood of several circulatory regions: A method for studying kinetics of histamine release in the whole animal. Agents Actions 4:336-356

31. Lorenz W, Barth H, Karges HE, Schmal A, Dormann P, Niemeyer I (1974c) Problems in the assay of histamine release by gelatin: o-phthaldialdehyde-induced fluorescence, inhibition of histamine methyltransferase and $\mathrm{H}_{1}$-receptor antagonism by Haemaccel. Agents Actions 4:324-335

32. Lorenz W, Barth H, Thermann M, Schmal A, Dormann P, Niemeyer I (1974d) Fluorometric histamine determination in canine plasma under normal conditions, following application of exogenous histamine and during histamine release by Haemaccel. Hoppe-Seyler's Z Physiol Chem 355:1097-1111

33. Lorenz W (1975) Histamine release in man. Agents Actions $5: 402-416$

34. Lorenz W, Doenicke A, Messmer K. Reimann H-J, Thermann M, Lahn W, Berr J, Schmal A, Dormann P, Regenfuss P, Hamelmann $\mathrm{H}$ (1976) Histamine release in human subjects by modified gelatin (Haemaccel) and dextran: An explanation for anaphylactoid reactions observed unter clinical conditions? $\mathrm{Br}$ J Anaesthesia 48:151-165

35. Lorenz W, Doenicke A, Dittmann I, Hug P, Schwarz B (1977) Anaphylaktoide Reaktionen nach Application von Blutersatzmitteln beim Menschen: Verhinderung dieser Nebenwirkung von Haemaccel druch Prämedikation mit $\mathrm{H}_{1}$ - und $\mathrm{H}_{2}$-Rezeptorantagonisten. Anaesthesist 26:644-648

36. Lorenz W, Doenicke A (1978a) Anaphylactoid reactions and histamine release by intravenous drugs used in surgery and anaesthesia. In: Watkins J, Ward AM (eds) Adverse response to intravenous drugs. Academic Press, London; Grune and Stratton, New York, pp 83-112

37. Lorenz W, Doenicke A (1978b) Histamine release in clinical conditions. Mount Sinai J Med 45:357-386

38. Lorenz W. Doenicke A, Schöning B, Mamorksi I, Weber D, Hinterlang E, Schwarz B, Neugebauer E (1980) $\mathrm{H}_{1}+\mathrm{H}_{2}$-receptor antagonists for premedication in anaesthesia and surgery: $A$ critical view basing on randomized clinical trials with Haemaccel and various antiallergic drugs. Agents Actions 10:114-124

39. Lorenz W, Doenicke A, Schöning B, Neugebauer E (1981 a) The role of histamine in adverse reactions to intravenous agents. In: Thornton JA (ed) Adverse reactions of anaesthetic drugs. Elsevier/North-Holland, Amsterdam, pp 169-238

40. Lorenz W, Doenicke A, Schöning B, Karges H, Schmal A (1981 b) Incidence and mechanisms of adverse reactions to polypeptides in man and dog. In: Hennessen W (ed) Standardization of albumin, plasma substitutes and plasma-pheresis. International Symposium WHO/IABS. Development of biological standard, vol 48. Karger, Basel, pp 207-304

41. Lorenz W, Ohmann Ch, Immich H, Schreiber RL, Scheibe O, Herfarth Ch, Feifel G, Beger H (1982a) Bericht über die zweite Arbeitstagung der Chirurgischen Arbeitsgemeinschaft für klinische Studien der Deutschen Gesellschaft für Chirurgie. Chirurg (in press)

42. Lorenz W, Schmal A, Schult H, Lang S, Weber D, Lüben L, Kapp B (1982b) Histamine release in dogs by wetting agents: Analysis of various components in cremophor El and development of a compound with reduced toxicity. Agents Actions $12: 64-80$

43. Lusted LB (1968) Introduction to medical decision making. CH. C. Thomas, Springfield, IL, pp 1-279
44. Messmer K, Lorenz W, Sunder-Plassmann L, Klövekorn W, Hutzel M (1970) Histamine release as cause of acute hypotension following rapid colloid infusion. Naunyn-Schmiedebergs Arch Pharmakol 267:433-445

45. Moss J, Rosow CD, Savarese JJ, Philbin DM, Kniffen KF (1981) Role of histamine in the hypotensive action of d-tubocurarine in humans. Anesthesiology 55:19-25

46. O'Duffy G, Chahl LA (1970) The influence of laboratory anaesthetics on the increased cutaneous vascular permeability responses to histamine and 5-hydroxytryptamine in rats. J Pharmacol Methods 4:231-235

47. Paton WDM (1958) Release of histamine. Progr Allergy 5:79-148

48. Parkin JV, Lorenz W, Barth H, Rohde $\mathrm{H}$, Ohmann $\mathrm{Ch}$, Thon $\mathrm{K}$, Weber, D, Crombach M (1982) Assay and identification of histamine in human gastric aspirate by a fluorometric-fluoroenzymatic technique. Its application in patients with chronic duodenal ulcer. Agents Actions 12:17-25

49. Pavek K (1977) Anaphylactic shock in the monkey: its hemodynamics and mediators. Acta Anaesthesiol Scand 21:293-307

50. Pavek K, Piper PJ, Smedegard G (1977) Anaphylatoxin-induced shock and two patterns of anaphylactic shock: hemodynamics and mediators. Acta Physiol Scand. 105:393-403

51. Philbin DM, Moss $\mathfrak{J}$, Akins CW, Rosow CE, Kono K, Schneider RC, Ver Lee ThR, Savarese JJ (1981) The use of $\mathrm{H}_{1}$ and $\mathrm{H}_{2}$-histamine antagonists with morphine anesthesia: a double-blind study. Anesthesiology 55:292-296

52. Ring J, Messmer K (1977) Incidence and severity of anaphylactoid reactions to colloid volume substitutes. Lancet 1:466-469

53. Rothschild AM (1966) Histamine release by basic compounds. In: Rocha e Silva M, Rothschild HA (eds) Histamine and antihistaminics. Handbook of experimental pharmacology, vol 18/1. Springer, Berlin Heidelberg New York, pp 386430

54. Schöning B, Koch H (1975) Pathergiequote verschiedener Plasmasubstitute an Haut und Respirationstrakt orthopädischer Patienten. Anaesthesist 24:507-516

55. Schöning B, Lorenz W (1981 a) Prevention of allergoid (cutaneous anaphylactoid) reactions to polygeline (Haemaccel) in orthopaedic patients by premedication with $\mathrm{H}_{1}$ - and $\mathrm{H}_{2}$-receptor antagonists. In: Hennessen W (ed) Standardization of albumin, plasma substitutes and plasma-pheresis. International Symposium WHO/IABS, Development of biological standard, vol 48. Karger, Basel, pp 241-249

56. Schöning B, Lorenz W (1981 b) Anaphylaktoide Reaktionen. Klinikarzt 10:621-633

57. Schöning B, Lorenz W, Doenicke A (1982) Prophylaxis of anaphylactoid reactions to a polypeptidal plasma substitute by $\mathrm{H}_{1^{-}}$ and $\mathrm{H}_{2}$-receptor antagonists: Synopsis of three randomized controlled trials. Klin Wochenschr 60:1048-1055

58. Seidel G, Groppe $G$, Meyer-Burgdorff C (1974) Contrast media as histamine liberators in man. Agents Actions $4: 143-150$

59. Serafini W (1976) L'histamine dans l'allergie humaine. In: Roche e Silva M, Rothschild HA (eds) Histamine and antihistaminics, vol 18/1. Springer, Berlin Heidelberg New York, pp 899-917

60. Smedegård G, Revenäs, B. Lundberg C, Arfors K-E (1981) Anaphylactic shock in monkeys passively sensitized with human reaginic serum. I. Hemodynamics and cardiac performance. Acta Physiol Scand 111:239-247

61. Smith PHL, Kagey-Sobotka A, Bleecker ER, Traystman R, Kaplan AP, Gralnick H, Valentine MD, Permutt S, Lichtenstein LM (1980) Physiological manifestations of human anaphylaxis. J Clin Invest 66:1072-1080

62. Stevenson DD, Arroyave CM, Bhat KN, Tan EM (1976) Oral aspirin challenges in asthmatic patients : a study of plasma histamine. Clin Allergy 6:493-505

62a. Strackham K (1977) Vergleichende Untersuchung über die Volumenwirkung einer Zweidrittel-Elektrolytlösung sowie einer 4\%igen Dextranlösung in der Phase der Narkoseeinleitung. Infusionstherapie 4:129-132 
63. Uvnäs B (1981) Comment in the Symposium on Histamine and Antihistaminics, Munich

64. Watkins J, Clarke RSJ (1978) Report of a symposium: adverse responses to intravenous agents. $\mathrm{Br} \mathrm{J}$ Anaesthesiol 50:1159-1164

65. Watkins J (1979) Anaphylactoid reactions to i.v. substances. Br J Anaesthesia 51:51-60

66. Watkins J (1981) Mechanisms and factors predisposing towards adverse response to intravenous anaesthetic substances. In: Thornton JA (ed) Adverse reactions to anaesthetic drugs. Excerpta Medica/Elsevier North-Holland, Amsterdam, pp 137 167

67. Weber E (1980) Schäden nach Langzeitbehandlung. In:
Schnieders B, Grosdanoff P (eds) Zur Problematik von chronischen Toxizitätsprüfungen. Reimer, pp 217-222

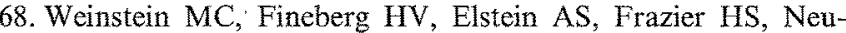
hauser D, Neutra RR, McNeil BJ (1980) Clinical decision analysis. Saunders, Philadelphia, pp 1-351

69. Weiss S, Robb GP, Ellis LB (1932) The systemic effects of histamine in man. With special reference to the responses of the cardiovascular system. Arch Intern Med 49:360396

70. Wolstenholme GWW, O'Connor CM (1956) Ciba foundation Symposion on Histamine. Churchill, London, pp 1-472

71. Wulff HR (1976) Rational diagnosis and treatment. Blackwell, Oxford, pp 1-182 
Appendix 1. Recommendations for performing the interview and the clinical investigations: Ask the general questions at the beginning of every section. When clinical symptoms are detected please sign by a cross if they occur before infusion of drug injection. After drug administration note the mins of onset and disappearance.

The authors thank very much $\mathrm{A}$. Thornton and J. Watkins (University of Sheffield) for their help in the translation of this questionnaire. For continuous registration of heart rate and blood pressure a separate protocol was used. For additional informations about the symptoms of this questionnaire see Lorenz et al. (1981 a). Present $=$ from 9 months in the past until now (the moment of interview), past $=$ more than 9 months ago. Only in a few exceptions a more exact denotion of time was considered necessary (e.g. anaesthetics, operations and trauma). In clinical findings sometimes more than one time had to be recorded for disappearance of a clinical symptom for reasons of accuracy. In this case the last number is the time finally accepted. "Coughing" has to be differentiated from "clearing one's throat" because otherwise the incidence of false-positive systemic responses is actually doubled or in the case of plasma substitutes tripled (short-term overload of the lung with fluid?). "Acceleration" or "slowing down" refers to the speed of infusion

Questionnaire for diagnosis of a histamine-release response

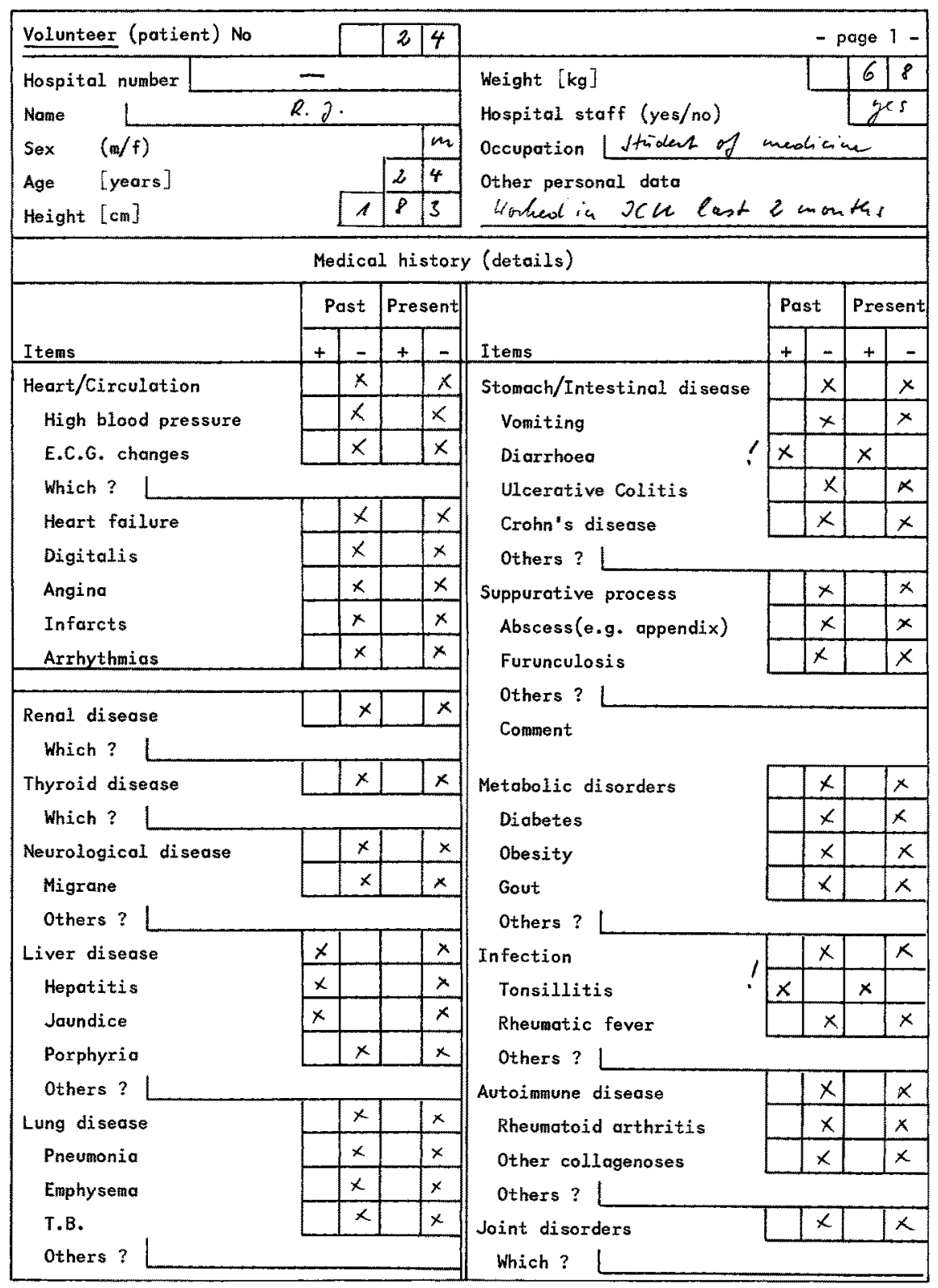


Questionnaire continued

\begin{tabular}{|c|c|c|c|c|c|}
\hline \multirow[b]{2}{*}{ Symptom } & \multicolumn{3}{|c|}{ Clinical findings } & \multicolumn{2}{|c|}{ - page 3 - } \\
\hline & $\begin{array}{l}\text { Be- } \\
\text { fore }\end{array}$ & {$\left[\begin{array}{c}\text { After } \\
{[\text { min - min }}\end{array}\right]$} & Symptom & $\begin{array}{l}\text { Be- } \\
\text { fore }\end{array}$ & $\begin{array}{c}\text { After } \\
\text { [min - min }\end{array}$ \\
\hline \multirow{3}{*}{$\begin{array}{l}\text { Anything peculiar? } \\
\text { Metallic taste } \\
\text { Others? L }\end{array}$} & - & 二 & \multirow{9}{*}{$\begin{array}{l}\text { Snezzing } \\
\text { Snuff ing } \\
\text { Stuffed-up nose } \\
\text { Nasal catarrh } \\
\text { Narrowness in the chest } \\
\text { Cough } \\
\text { Respiratory distress } \\
\text { Bronchospasm } \\
\text { Others? }\end{array}$} & - & $x-4$ \\
\hline & $\neg$ & $3-7$ & & - & $1-4$ \\
\hline & & & & - & $1-4-16$ \\
\hline \multirow{8}{*}{$\begin{array}{l}\text { Salivary secretion } \\
\text { Tight throat } \\
\text { Epigastric fullness } \\
\text { Nousea } \\
\text { Heort burn } \\
\text { Cromps, colics } \\
\text { Straining } \\
\text { Others? }\end{array}$} & - & $4-16$ & & - & $4-20$ \\
\hline & - & $3-10$ & & - & $2-10$ \\
\hline & $=$ & - & & \multicolumn{2}{|c|}{$=8-14-16$} \\
\hline & - & $=$ & & - & $4-10$ \\
\hline & - & - & & \multirow[t]{2}{*}{$=$} & \multirow[t]{2}{*}{-} \\
\hline & $=$ & - & & & \\
\hline & - & - & \multirow{3}{*}{$\begin{array}{l}\text { Blurred sight } \\
\text { Wet eyes }\end{array}$} & \multirow{3}{*}{ - } & \multirow{2}{*}{-} \\
\hline & & & & & \\
\hline \multirow{11}{*}{$\begin{array}{l}\text { Sensation of heat } \\
\text { Red ears } \\
\text { Erythema } \\
\text { Flush } \\
\text { Swollen ears } \\
\text { Blepharoedema } \\
\text { Hives (wheals) } \\
\text { Pruritus } \\
\text { Conjunctivitis } \\
\text { Quincke's oedema } \\
\text { Others? L }\end{array}$} & - & $1-5$ & & & \\
\hline & - & $=$ & \multirow{7}{*}{$\begin{array}{l}\text { Unrest ? } \\
\text { Sweating } \\
\text { Tiredness } \\
\text { Anxiety } \\
\text { Palpitation } \\
\text { Other vegetative } \\
\text { symptoms }\end{array}$} & - & - \\
\hline & - & - & & $x$ & $1-2 v$ \\
\hline & - & - & & - & - \\
\hline & - & - & & - & $=$ \\
\hline & - & $2-3 D$ & & - & - \\
\hline & - & $6-16$ & & & \\
\hline & - & $6-12$ & & & \\
\hline & - & - & Desire to pass water & - & $=$ \\
\hline & - & - & Low back pain & $=$ & - \\
\hline & & & Feeling of -body & - & $1-10$ \\
\hline Tinnitus & - & - & heaviness -feet & - & $1-10$ \\
\hline Congestion in the head & $=$ & - & Others? L & & \\
\hline Temporal pulsation & $=$ & - & Time for bleeding [min] & & 3.10 \\
\hline Headache & - & $=$ & Time for infusion [min] & & 3 \\
\hline Where? $L$ & & & Any slowing down? & & no \\
\hline Drowsiness & $=$ & - & Any acceleration? & & no \\
\hline Dizziness & $=$ & - & Photo taken & & ho \\
\hline Hang-over & - & - & Any comment ? & & \\
\hline others ? L & & & sorelling of the vea & & ef(t) \\
\hline
\end{tabular}


Questionnaire continued

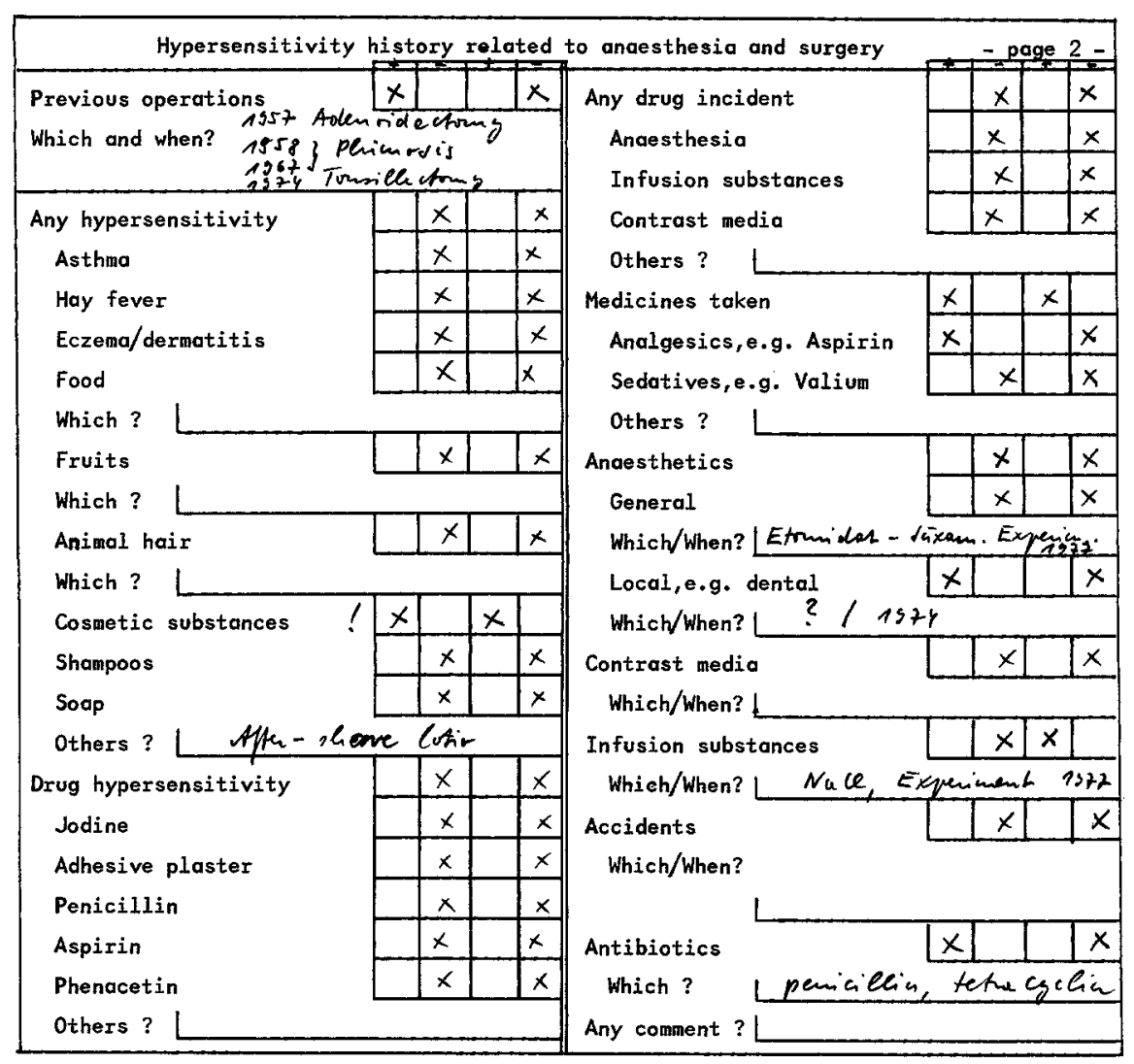

